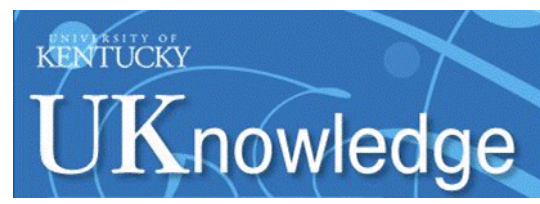

University of Kentucky

UKnowledge

Kentucky Geological Survey Report of Investigations

2015

\title{
Geologic, Geotechnical, and Geophysical Investigation of a Shallow Landslide, Eastern Kentucky
}

\author{
Matthew M. Crawford \\ University of Kentucky, mcrawford@uky.edu \\ Junfeng Zhu \\ University of Kentucky, junfeng.zhu@uky.edu \\ Steven E. Webb \\ University of Kentucky, sewebb4@email.uky.edu
}

Follow this and additional works at: https://uknowledge.uky.edu/kgs_ri

Part of the Environmental Monitoring Commons, and the Geology Commons

Right click to open a feedback form in a new tab to let us know how this document benefits you.

\section{Repository Citation}

Crawford, Matthew M.; Zhu, Junfeng; and Webb, Steven E., "Geologic, Geotechnical, and Geophysical Investigation of a Shallow Landslide, Eastern Kentucky" (2015). Kentucky Geological Survey Report of Investigations. 31.

https://uknowledge.uky.edu/kgs_ri/31

This Report is brought to you for free and open access by the Kentucky Geological Survey at UKnowledge. It has been accepted for inclusion in Kentucky Geological Survey Report of Investigations by an authorized administrator of UKnowledge. For more information, please contact UKnowledge@lsv.uky.edu. 
Kentucky Geological Survey

University of Kentucky, Lexington

Geologic, Geotechnical, and Geophysical Investigation of a Shallow Landslide, Eastern Kentucky

Matthew M. Crawford, Junfeng Zhu, and Steven E. Webb 


\title{
Our Mission
}

Our mission is to increase knowledge and understanding of the mineral, energy, and water resources, geologic hazards, and geology of Kentucky for the benefit of the Commonwealth and Nation.

\section{Earth Resources-Our Common Wealth}

\author{
www.uky.edu/kgs
}

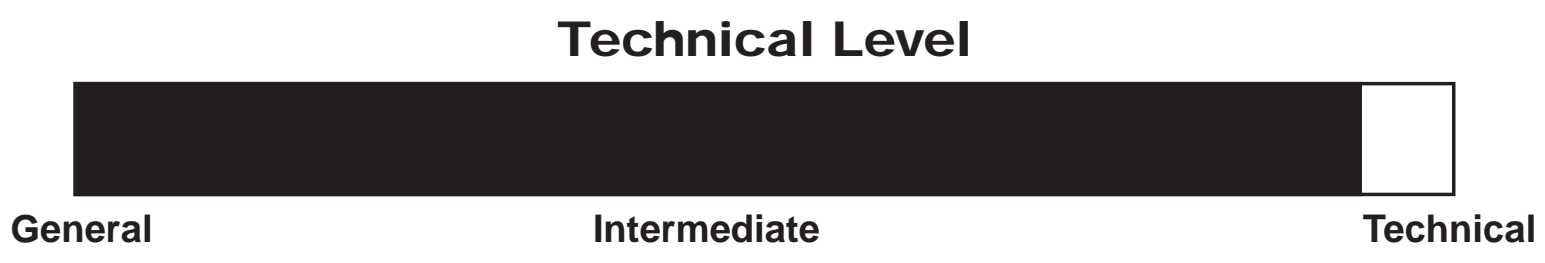




\section{Contents}

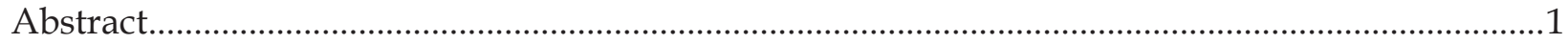

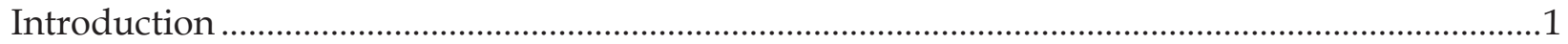

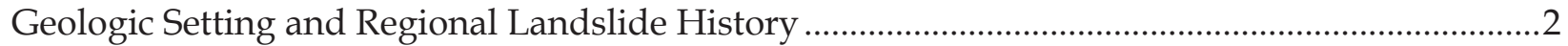

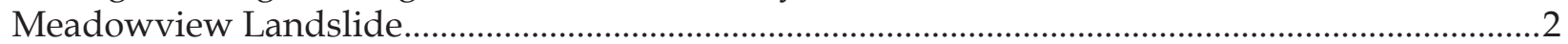

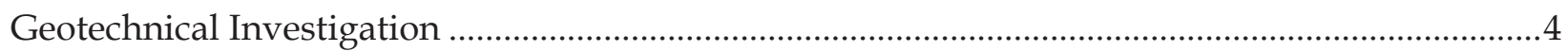

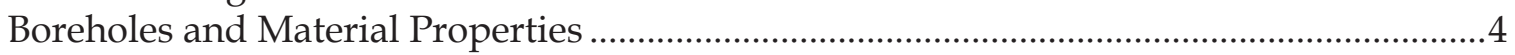

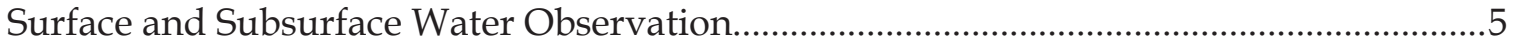

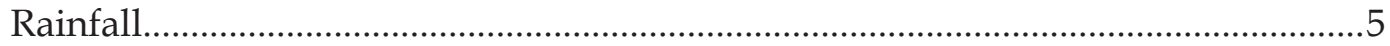

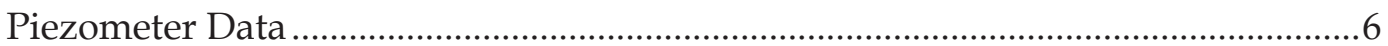

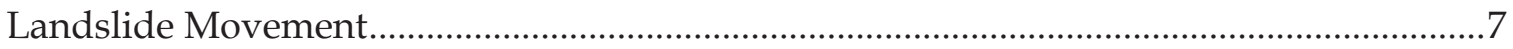

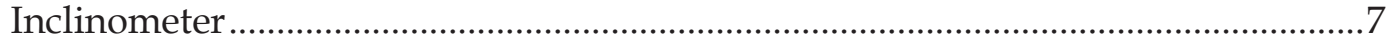

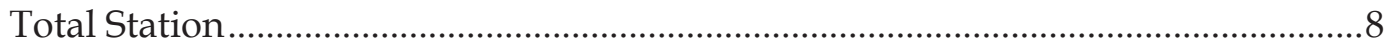

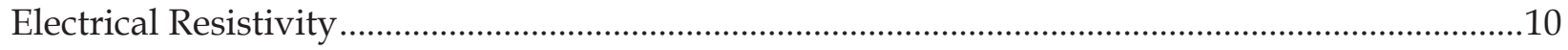

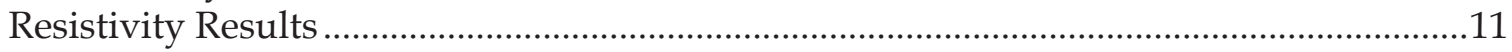

Example Inverted Resistivity Sections.................................................................12

MVS1, 7/26/2013: Parallel to the Landslide Axis in the Downslope

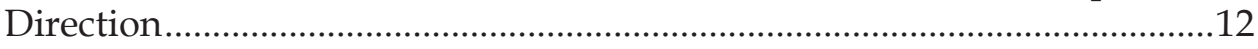

MVS2, 7/26/2013: Perpendicular to the Downslope Direction, Upper

Slope ........................................................................................................13

MVS3, 7/26/2013: Perpendicular to the Downslope Direction, Toe

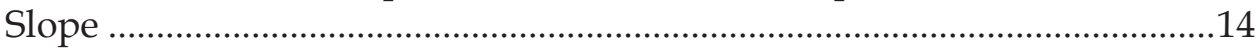

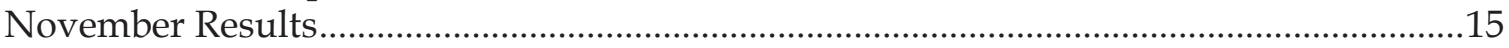

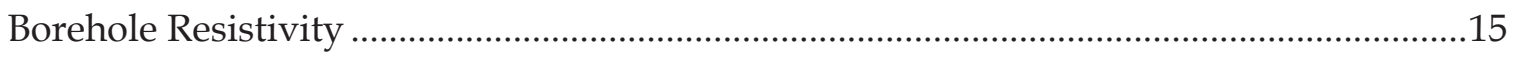

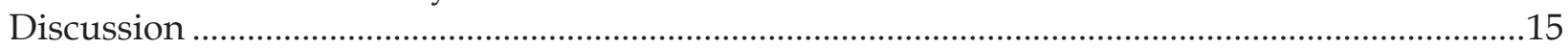

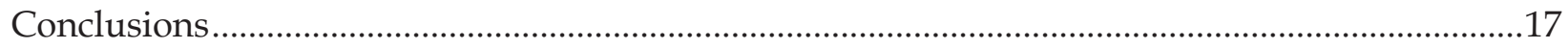

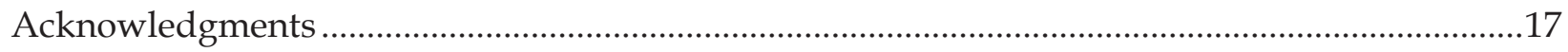

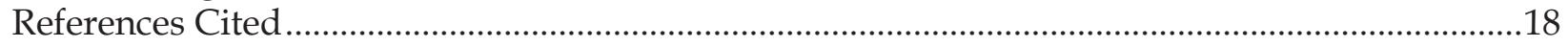

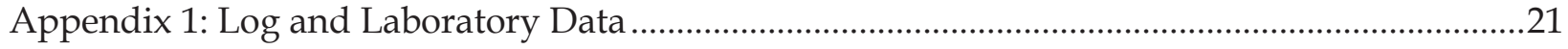

Appendix 2: Cumulative and Incremental Inclinometer Data ........................................................37

\section{Figures}

1. Map showing locations of the project area, Appalachian Plateau, eastern Kentucky,

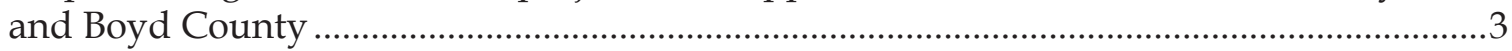

2. Hillshade geologic map showing the location of the Meadowview landslide....................4

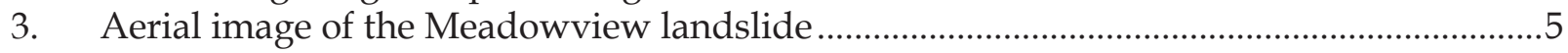

4. Graph showing daily rainfall measured at the Meadowview landslide ............................6

5. Graph showing maximum daily groundwater levels measured from the pressure recorder in borehole B1 compared with daily rainfall from June 26 through September

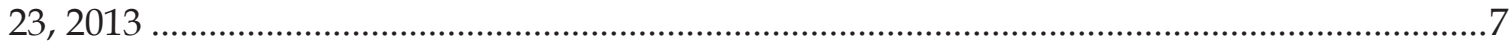

6. Graph showing inclinometer displacement versus time in boreholes B1 and B3, plotted

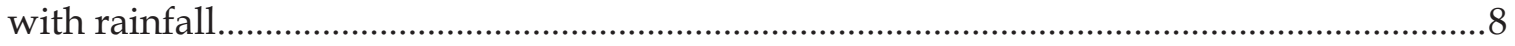

7. Aerial photograph showing locations of total station monuments...................................9

8. Georeferenced coordinate system showing surface displacement of all eight monuments

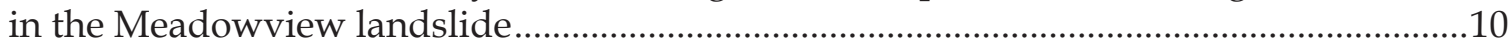

9. Graph showing movement of total station monument S3 over time .................................11

10. Diagram showing electrical-resistivity array locations in the Meadowview landslide ....12 


\section{Figures \\ (continued)}

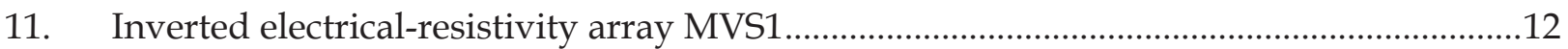

12. Graph showing vertical electrical-resistivity profile at borehole B1 .................................13

13. Graph showing vertical-resistivity profile taken midslope from section MVS1 ...............14

14. Inverted-resistivity profile MVS2 in a transverse direction, below the head scarp of

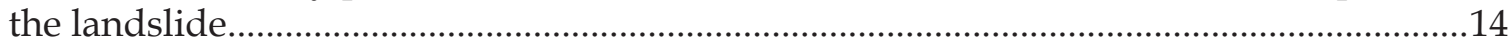

15. Inverted-resistivity profile MVS3 perpendicular to the downslope direction, along the toe of the landslide .15

16. Inverted-electrical-resistivity array MVS1-2, measured in November 2013 ......................15

17. Inverted-electrical-resistivity array MVS2-2, measured in November 2013 .....................16

18. Inverted-electrical-resistivity array MVS3-2, measured in November 2013 .....................16

19. Borehole resistivity results from June 14, 2013 ..........................................................16

\section{Table}

1. Summary of the material properties from borehole samples and logs of the Meadowview landslide 


\title{
Geologic, Geotechnical, and Geophysical Investigation of a Shallow Landslide, Eastern Kentucky
}

\section{Matthew M. Crawford, Junfeng Zhu, and Steven E. Webb}

\begin{abstract}
In eastern Kentucky, landslides occur in colluvial soils or at the colluvium-bedrock contact, and are commonly triggered by heavy rainfall. These slides occur particularly where steep slopes and weak rocks combine with various methods of slope modification. Landslides can damage roadways, infrastructure, and residences, and mitigation costs can exceed $\$ 10$ million per year.

The Meadowview landslide in Boyd County was investigated to assess the geologic conditions, extent, and behavior of a rainfall-triggered landslide in eastern Kentucky and evaluate the use of electrical resistivity as a tool to characterize a shallow colluvial landslide. Although this type of landslide is common in Kentucky, there are few comprehensive landslide characterization studies combining geologic, geotechnical, and geophysical assessment. This study successfully used traditional geologic and geotechnical data to characterize an active landslide and electrical resistivity to interpret landslide stratigraphy, moisture regimes, and depth to the slide plane. The surface and borehole electrical-resistivity arrays across the Meadowview landslide resulted in inverted resistivity sections with distinct resistivity contrasts that correlate to landslide stratigraphy, depth of slide plane, and groundwater regimes.
\end{abstract}

\section{Introduction}

In eastern Kentucky, landslides mainly occur in colluvial soils that mantle steep slopes and easily weathered rocks. Colluvium varies in thickness and composition across the state, primarily depending on slope morphology and rock type. Landslides commonly triggered by heavy rainfall damage roadways, infrastructure, and residences; mitigation costs exceed \$10 million per year (Crawford, 2014; Overfield, in press). This study investigated the Meadowview landslide, which occurred in Boyd County, in April 2011. It was caused by a combination of natural and manmade factors.
Local geology, steep slope, house foundation excavation, vegetation removal, and fill placement contributed to the landslide. The purpose of this project was to assess the geologic conditions, geometry, and behavior of a rainfall-triggered landslide in eastern Kentucky and evaluate the use of electrical resistivity as a tool to characterize a shallow colluvial landslide. A variety of instruments, sensors, and laboratory testing was used to collect information on meteorologic and hydrologic conditions and landslide movement. A slope inclinometer and total station survey system monitored landslide movement. Piezometers and a rain gage 
collected groundwater and rainfall data, respectively. Laboratory analysis conducted by Terracon Inc. provided material index and strength properties. An eight-channel resistivity meter measured surface and borehole electrical resistivity.

This type of landslide is common in Kentucky, but there are few publicly available, comprehensive landslide characterization studies that include geophysical analysis. Transportation officials mitigate landslides along roadways, but very few other government agencies analyze landslide hazards, and if they do, their results are not made public or are difficult to access. Private geotechnical engineering firms investigate landslides and provide mitigation services, but the data in their reports are not typically accessible to the public. The data collected and interpreted in this project provide detailed analysis for one landslide, but can serve as an example for future landslide hazard studies that combine geotechnical and geophysical techniques to investigate shallow colluvial landslides.

\section{Geologic Setting and Regional Landslide History}

Eastern Kentucky is located in the east-central Appalachian Plateau, part of the larger southern Appalachian Basin. This physiographic region extends from Pennsylvania into parts of Ohio, West Virginia, Kentucky, Virginia, and Tennessee (Gray and others, 1979; Radbruch-Hall and others, 1982; Outerbridge, 1987a) (Fig. 1). The plateau is highly dissected with relief that ranges from approximately 120 to $300 \mathrm{~m}$. Interbedded clastic sedimentary rocks of Paleozoic age dominate the region. Steep slopes have high incidences of landslides, and landslide susceptibility stems from particular bedrock lithologies and colluvial soils (Gray and Gardner, 1977; Outerbridge, 1987b).

This region is prone to landslide hazards, particularly during large precipitation events. In 1998, storms produced $165 \mathrm{~mm}$ of rain in $72 \mathrm{hr}$ over southeastern Ohio, causing six fatalities and millions of dollars in property and infrastructure damage (Shakoor and Smithmyer, 2005). In July 1939, in Wolfe and Breathitt Counties, Ky., $508 \mathrm{~mm}$ of rain fell during a thunderstorm over 2 days, causing four debris flows (Wieczorek and Morgan, 2008). Flash flooding in Virgie, Ky., in May 1999 caused several damaging debris flows (National
Oceanic and Atmospheric Association, National Weather Service, Jackson, Ky., July 13, 2011, personal communication). Persistent rainfall totaling 381 to $457 \mathrm{~mm}$ across eastern Kentucky from late April to mid-May 2011 caused more than 60 landslides. A short, intense storm that dropped approximately $90 \mathrm{~mm}$ of rain in $3 \mathrm{hr}$ over a very localized area caused a large, damaging landslide in Powell County, Ky. (Crawford, 2012). These examples are all shallow colluvial mass-wasting events, in which slope morphology, colluvium thickness, composition, water conditions, changes in load, and changes in frictional resistance are factors affecting stability.

\section{Meadowview Landslide}

The Meadowview landslide is located in Boyd County, eastern Kentucky. The bedrock in the area consists of interbedded shale, underclay, sandstones, and coals of the Princess Formation (Fig. 2). Identifying slope geomorphology is an important part of assessing landslide susceptibility. Natural colluvial soils accumulate in concave parts of slopes, and often have high landslide incidences. There is evidence of preexisting landslide activity along the ridge, adjacent to the main slide area, including old (historic?) scarps, hummocky topography, and bent tree trunks.

Plastic and semiplastic shales and underclays are highly impermeable and the least competent rocks in the area (Dobrovolny and others, 1963). Most landslides occur along the underclays where hillsides are steep. Many small landslides have occurred along these beds in hillside excavations for houses. These rocks develop sandy to clayey colluvial soils on the slopes and residual soils on the ridgetops. Colluvium ranges in thickness from 1 to $3 \mathrm{~m}$. The landslide material consists of colluvium with added disturbed material from foundation excavation. The colluvium and excavated material observed at the surface is light brown, clayey to silty, with abundant shale and sandstone fragments. The soft clay soil is mottled gray and the silty shale fragments are micaceous. During bulldozing, an outcrop of gray, soft clay was exposed near the toe of the slide that correlates to the "clayey shale" described in the lithologic logs of boreholes at the site. Large sandstone slabs are also present in the slide material. During the excavation of the 

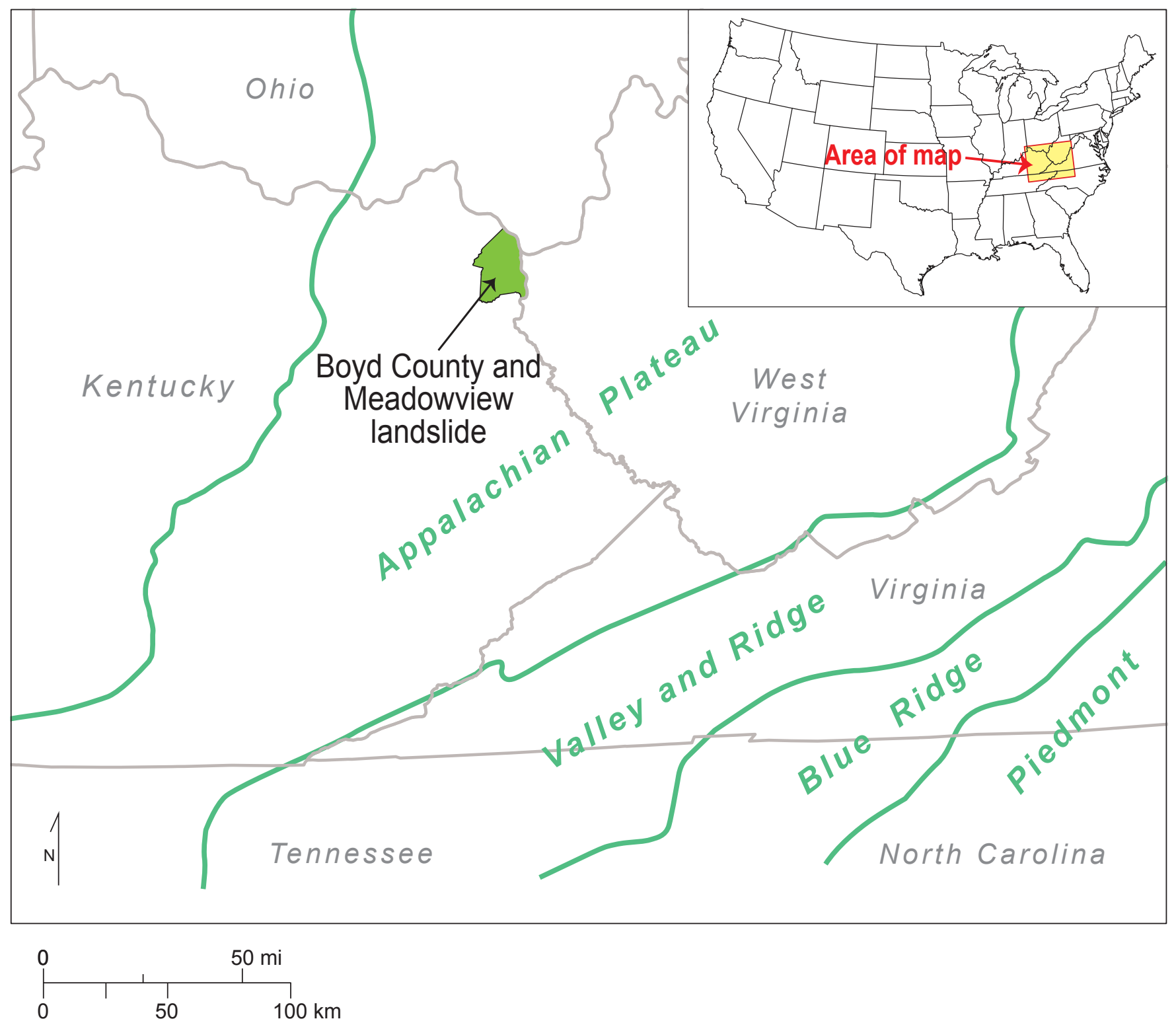

Figure 1. Locations of the project area, Appalachian Plateau, eastern Kentucky, and Boyd County.

house foundation, material was pushed down into a naturally concave part of the slope. The concavity was accentuated near the toe by additional excavation for a power line that leads from the base of the slope toward the crown of the slide.

The Meadowview landslide occurred in late April 2011 as approximately $203 \mathrm{~mm}$ of rain fell during the month (Community Collaborative Rain, Hail, and Snow Network, 2013; Kentucky Mesonet, 2013) and triggered the failure. The slope containing the slide ranges from approximately $13^{\circ}$ near the ridgetop, above the crown, and steepens to $16.7^{\circ}$ near the toe of the slide. The landslide occurred in a naturally concave part of the slope that is forested except for the trees and shrubs removed during excavation for residential construction. The landslide is active, containing multiple scarps, seeps, and small localized flows. Rotational movement occurred in the uppermost part of the landslide and, closer to the toe, the slide material morphed into a translational flow. The slide measures approximately $44 \mathrm{~m}$ along a southwestnortheast longitudinal axis and $40 \mathrm{~m}$ wide along a transverse axis near its middle (Fig. 3). The main scarp height ranges from a few centimeters at the flanks to approximately $1.5 \mathrm{~m}$ near the middle. 


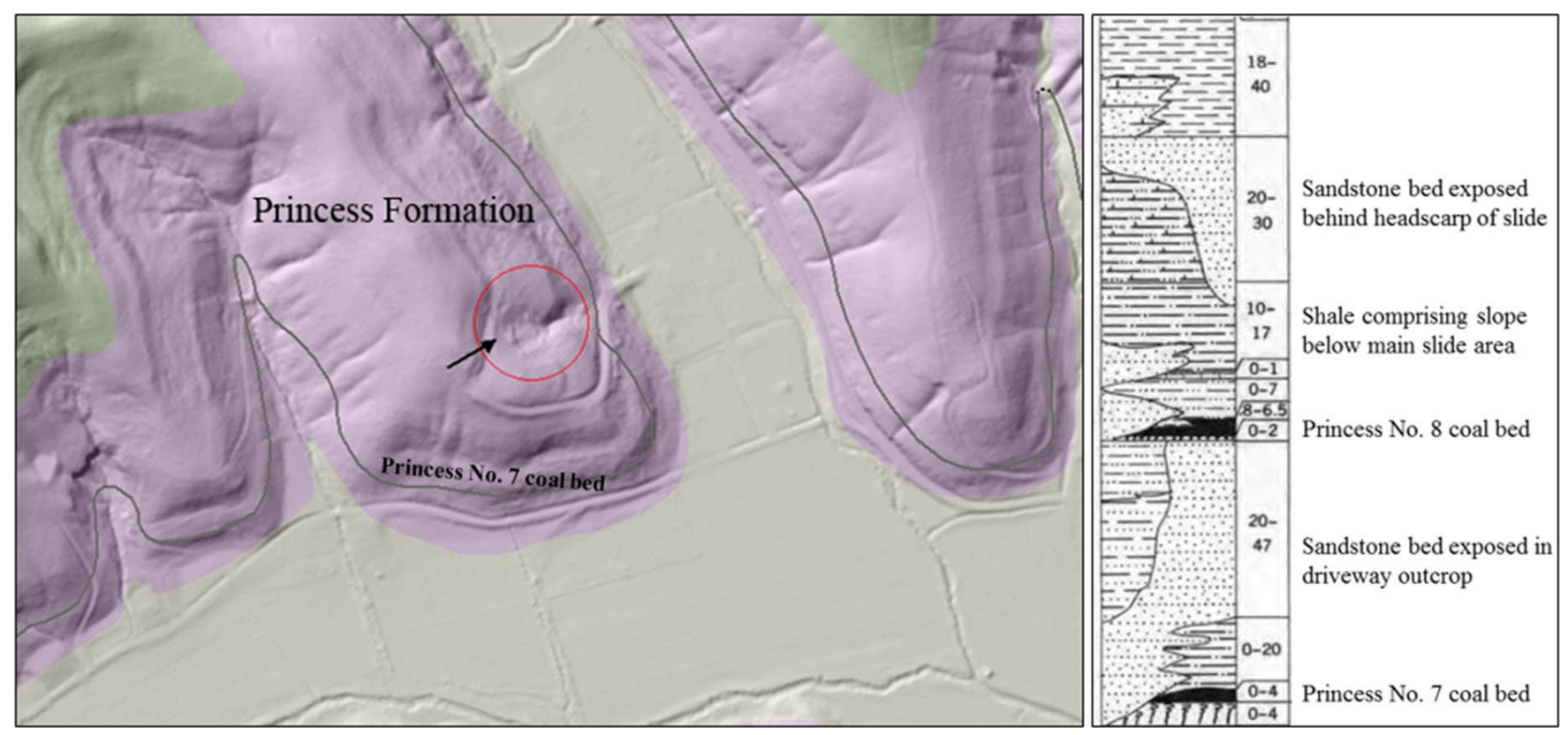

Figure 2. Hillshade geologic map showing the location of the Meadowview landslide (circled). The stratigraphic column shows the lithology of the Princess Formation.

The volume of material displaced by the landslide was calculated as approximately $2,517 \mathrm{~m}^{3}$, using the method of Cruden and Varnes (1996) and the Working Party on Worldwide Landslide Inventory (1990), assuming a half-ellipsoid shape and using a maximum depth of rupture (approximately $2.7 \mathrm{~m}$ ). A prominent secondary scarp is present approximately $10 \mathrm{~m}$ downslope from the head scarp. Small tension cracks occur on the flanks of the upper slide area. Seeps and high concentrations of water occur at the toe of the landslide.

\section{Geotechnical Investigation Boreholes and Material Properties}

Six boreholes were drilled into the Meadowview landslide (Fig. 2) on March 13-14, 2013. A 3.25-in. hollow-stem auger was used to core all boreholes. Continuous sampling with a standard-penetration-test split spoon (18-in.) obtained moisture content through most of the borehole. A summary of the material properties is shown in Table 1. Field soil descriptions are based on the American Society for Testing and Materials classification group names. Two boreholes (B1 and B3) were constructed with inclinometer casing, two boreholes (B2 and B4) were converted to open standpipe piezometers, and two boreholes (B5 and B6) were cased with slotted PVC and used for elec- trical-resistivity measurements. Boreholes B1 and B3 were logged and stratigraphy was interpreted.

Borehole B1 was drilled into bedrock to a total depth of $6.5 \mathrm{~m}$ and well below the assumed failure surface. The uppermost soil consisted of $2.7 \mathrm{~m}$ of disturbed colluvium, and water was encountered at a depth of $1.2 \mathrm{~m}$. The disturbed colluvium was divided into two types: $1.2 \mathrm{~m}$ of sandy, lean clay with gravel overlying $1.5 \mathrm{~m}$ of sandy, fat clay. The boundary between the two colluvial types may explain a difference in the disturbed material that came from excavation of a house foundation above the landslide and natural hillslope colluvium. Below the disturbed colluvium are three layers: $0.6 \mathrm{~m}$ of stiff to hard, fat clay; $0.76 \mathrm{~m}$ of weathered claystone; and $2.4 \mathrm{~m}$ of clayey shale. The boring was terminated at $6.5 \mathrm{~m}$ in weathered clayey shale. Soil density increased significantly at the contact between the two colluvium types and also between the native fat clay and weathered claystone. Field $\mathrm{N}$-values increased from 4 to 43 between the two colluvium types and 18 to 50 between the clay and claystone. Field $\mathrm{N}$-values are the number of blows (by a hammer) per foot during a standard penetration test required to drive a steel soil sampler into the ground.

Borehole B3 was drilled to a total depth of $4.7 \mathrm{~m}$. The uppermost soil consisted of $0.6 \mathrm{~m}$ of dis- 


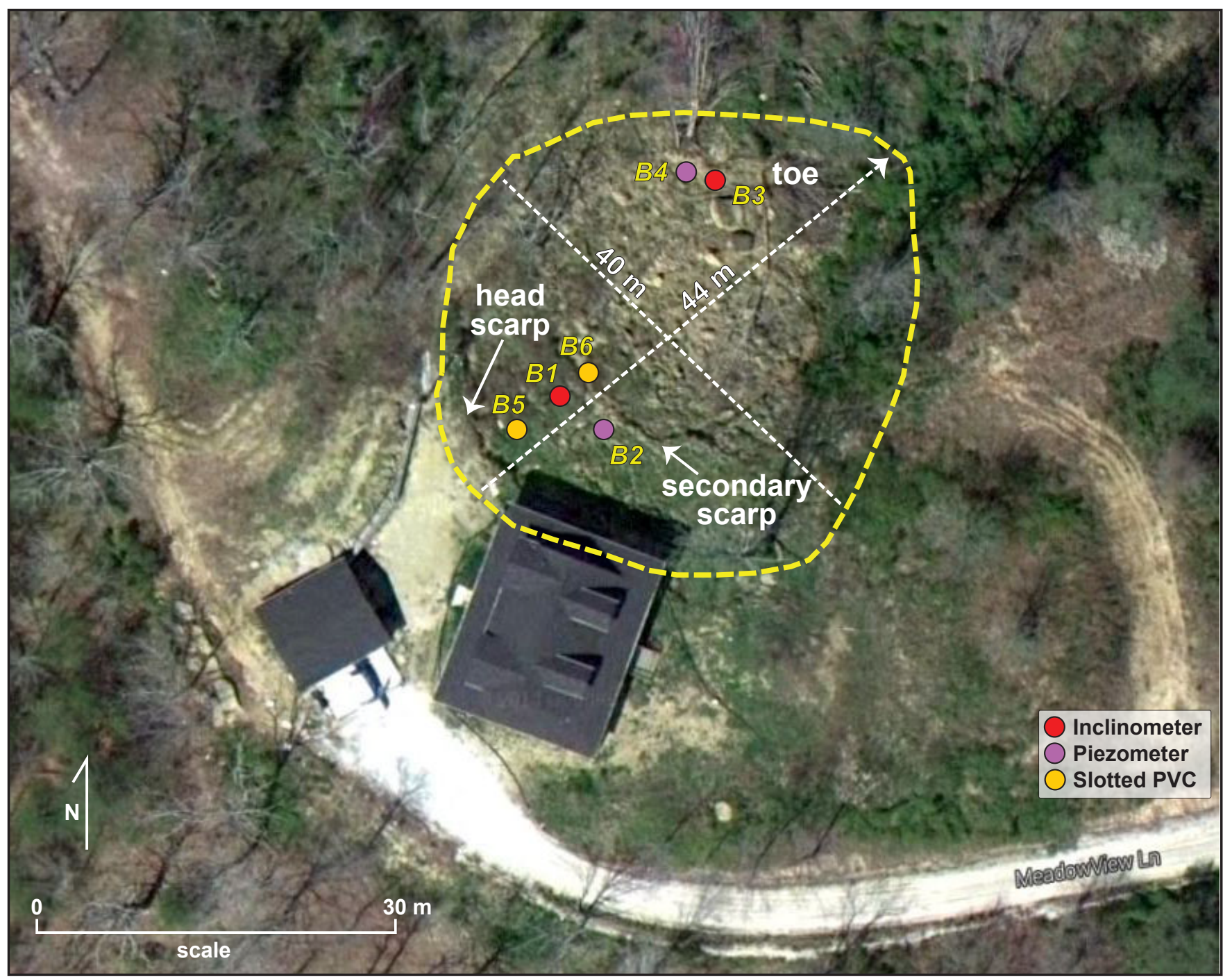

Figure 3. Aerial image of the Meadowview landslide. The main landslide area is within the dashed outline. Axes show dimensions of the slide. Borehole locations and instrumentation types also shown.

turbed colluvium, and groundwater was encountered near the surface. Below the fill is $1.8 \mathrm{~m}$ of lean clay and $2.7 \mathrm{~m}$ of clayey shale. Drilling was terminated when carbonaceous, laminated, weathered shale was encountered at about $4.7 \mathrm{~m}$ deep. Field $\mathrm{N}$-values increased at the lean clay-clayey shale contact, indicating an increase in density.

The complete $\log$ and laboratory data for borehole B1, provided by Terracon Consultants Inc., are available in Appendix 1. Laboratory data not described in the text include Atterberg limits, grain-size distribution, and triaxial shear strength. Total and effective stress parameters were determined from a consolidated undrained (with pore pressure) test.

\section{Surface and Subsurface Water Observation}

Rainfall. Rainfall data were collected by a tippingbucket rain gage. The gage consists of a stand-alone collector and recording system. The recorder can accumulate 1 yr of rainfall data with 1-min resolution. The tipping bucket was set with a $0.25 \mathrm{~mm} /$ tip threshold. We installed the rain gage on March 19, 2013. Total rainfall accumulation at the Meadowview landslide from installation to May 20, 2014 (14 mo), was 1,227.2 mm (Fig. 4). Average annual precipitation from 1981 to 2010 in nearby Ashland, Ky., was 1,122.7 mm (National Climatic Data Center, 2014). Considering the average annual precipi- 


\begin{tabular}{|c|c|c|c|c|c|c|c|}
\hline \multicolumn{8}{|c|}{ Borehole B1 } \\
\hline $\begin{array}{c}\text { Depth } \\
\text { (m) }\end{array}$ & Field Description & $\begin{array}{c}\text { Percent } \\
\text { Gravel }\end{array}$ & $\begin{array}{l}\text { Percent } \\
\text { Sand }\end{array}$ & $\begin{array}{l}\text { Percent } \\
\text { Silt }\end{array}$ & $\begin{array}{c}\text { Percent } \\
\text { Clay }\end{array}$ & $\begin{array}{l}\text { Plasticity } \\
\text { Index }\end{array}$ & $\begin{array}{c}\text { Field } \\
N \text {-Value }\end{array}$ \\
\hline $0-1.2$ & sandy lean clay with gravel (CL)_fill & 4.3 & 45.5 & 23.8 & 26.3 & 16 & 5 \\
\hline $1.2-1.5$ & sandy fat clay $(\mathrm{CH})$ - fill & 4.2 & 28.6 & 23.1 & 44.1 & $\mathrm{~N} / \mathrm{A}$ & 43 \\
\hline $1.5-2.7$ & sandy fat clay $(\mathrm{CH})$-fill & 9.1 & 41.4 & 19.4 & 30.1 & $\mathrm{~N} / \mathrm{A}$ & 5 \\
\hline $2.7-3.4$ & fat clay $(\mathrm{CH})$ & \multicolumn{4}{|c|}{ very stiff to hard, residual soil structure } & 16 & 18 \\
\hline $3.4-4.1$ & claystone & \multicolumn{5}{|c|}{ severely weathered, very soft } & 50 \\
\hline $4.1-6.5$ & clayey shale & \multicolumn{5}{|c|}{$\begin{array}{l}\text { thinly laminated, weathered, very soft, trace, thinly lami- } \\
\text { nated, interbedded sandy shale }\end{array}$} & $\mathrm{N} / \mathrm{A}$ \\
\hline \multicolumn{8}{|c|}{ Borehole B3 } \\
\hline $\begin{array}{l}\text { Depth } \\
(m)\end{array}$ & Field Description & $\begin{array}{l}\text { Percent } \\
\text { Gravel }\end{array}$ & $\begin{array}{l}\text { Percent } \\
\text { Sand }\end{array}$ & $\begin{array}{l}\text { Percent } \\
\quad \text { Silt }\end{array}$ & $\begin{array}{l}\text { Percent } \\
\text { Clay }\end{array}$ & $\begin{array}{l}\text { Plasticity } \\
\text { Index }\end{array}$ & $\begin{array}{l}\text { Field } \\
N \text {-Value }\end{array}$ \\
\hline $0-0.6$ & sandy lean clay with gravel (CL) & \multicolumn{5}{|c|}{ moderately stiff, micaceous, sandstone fragments } & 8 \\
\hline $0.6-1.8$ & lean clay $(C L)$ & 6.6 & 37.6 & 21.8 & 34.0 & 8 & 11 \\
\hline $1.8-4.6$ & clay shale & \multicolumn{4}{|c|}{ thinly laminated, weathered, very soft } & 9 & 24 \\
\hline $4.6-4.8$ & shale & \multicolumn{4}{|c|}{ carbonaceous, fissile, weathered, soft } & \multicolumn{2}{|c|}{ N/A } \\
\hline
\end{tabular}

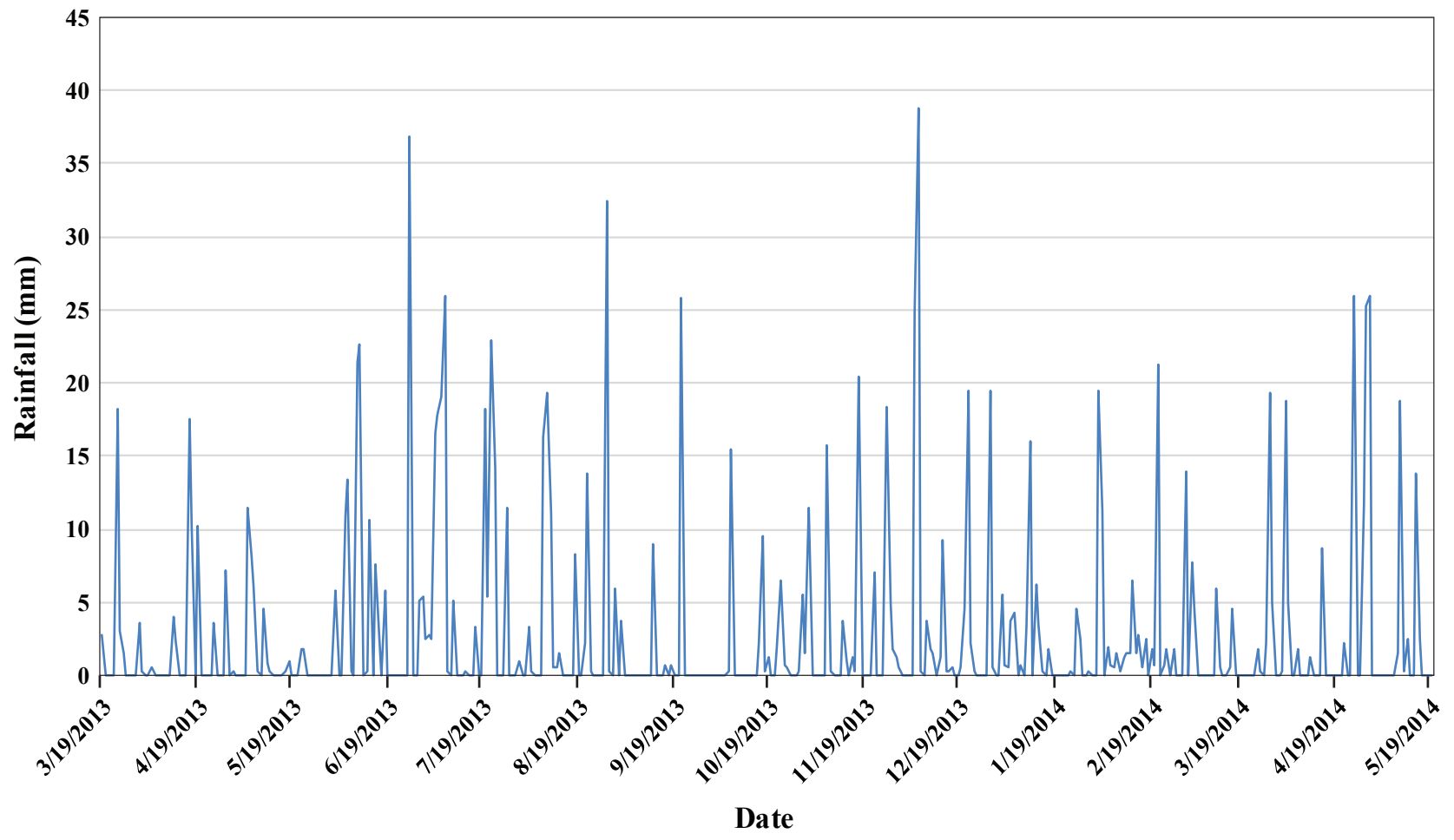

Figure 4. Daily rainfall measured at the Meadowview landslide.

tation in the area, the Meadowview landslide occurred during a slightly dry year.
Piezometer Data. Boreholes B2 and B4 were converted to open-standpipe piezometers and used to measure groundwater levels within the landslide 
mass. Piezometers were constructed with a slotted PVC casing consisting of a porous tip attached to the PVC pipe. The porous tip was isolated in the zone of interest with a bentonite seal. Water flows through the tip and can stabilize in the pipe, representing the piezometric surface. We recorded water levels using a water-level indicator consisting of an electronic probe and cable reel. The initial waterlevel readings in B2 and B4 (both 3-m total depth) were taken on March 19, 2013. We measured water levels once a week for the first $2 \mathrm{mo}$, then recorded monthly after that, because water levels did not fluctuate extensively.

Beginning on April 12, 2013, we also used a wireless, battery-powered pressure recorder to measure the groundwater levels in piezometer B2 (below the assumed failure zone). The recorder contains a pressure sensor that is placed at the bottom of the piezometer, measuring water level above the sensor. The sensor samples water levels at user-defined intervals. Elevated groundwater levels affect landslides, and precipitation that elevates the level to an instability threshold can often be the triggering mechanism. Field reconnaissance at the Meadowview landslide prior to drilling revealed the main landslide area to be very wet, especially near the toe. There were several seepage zones throughout the landslide. Based on our hydrostratigraphic model for the site, we inferred that observed shale beds were responsible for formation of perched water tables along the slope. Water flows along low-permeability clay shales, and seeps out where these beds intersect the surface.

We correlated groundwater fluctuations (measured in the piezometers) with rainfall. The largest pulses of rainfall caused an increase in groundwater level in the piezometers. A graph from late June to mid-September 2013 correlates increases in groundwater level above the bottom of the borehole with rainfall pulses (Fig. 5). In B2, groundwater level change above the sensor, after rainfall pulses, varied from $80 \mathrm{~mm}$ in spring of 2013 to $122 \mathrm{~mm}$ in spring of 2014. The timeframe for the groundwater increase ranged from 1 to 3 days following a rainfall pulse. The clayey colluvial fill stores a lot of water, which is perched on the low-permeability clay layers, controlling a smaller groundwater level response to rainfall.

\section{Landslide Movement}

Inclinometer. Inclinometer measurements were used to determine the magnitude, rate, direction, and depth of movement at boreholes B1 and B3. We used an inclinometer, which included a biaxial probe that contains two perpendicular accelerometers, in effect monitoring the displacement normal to the axis of the borehole casing. The baseline inclinometer reading was taken on March 25, 2013.

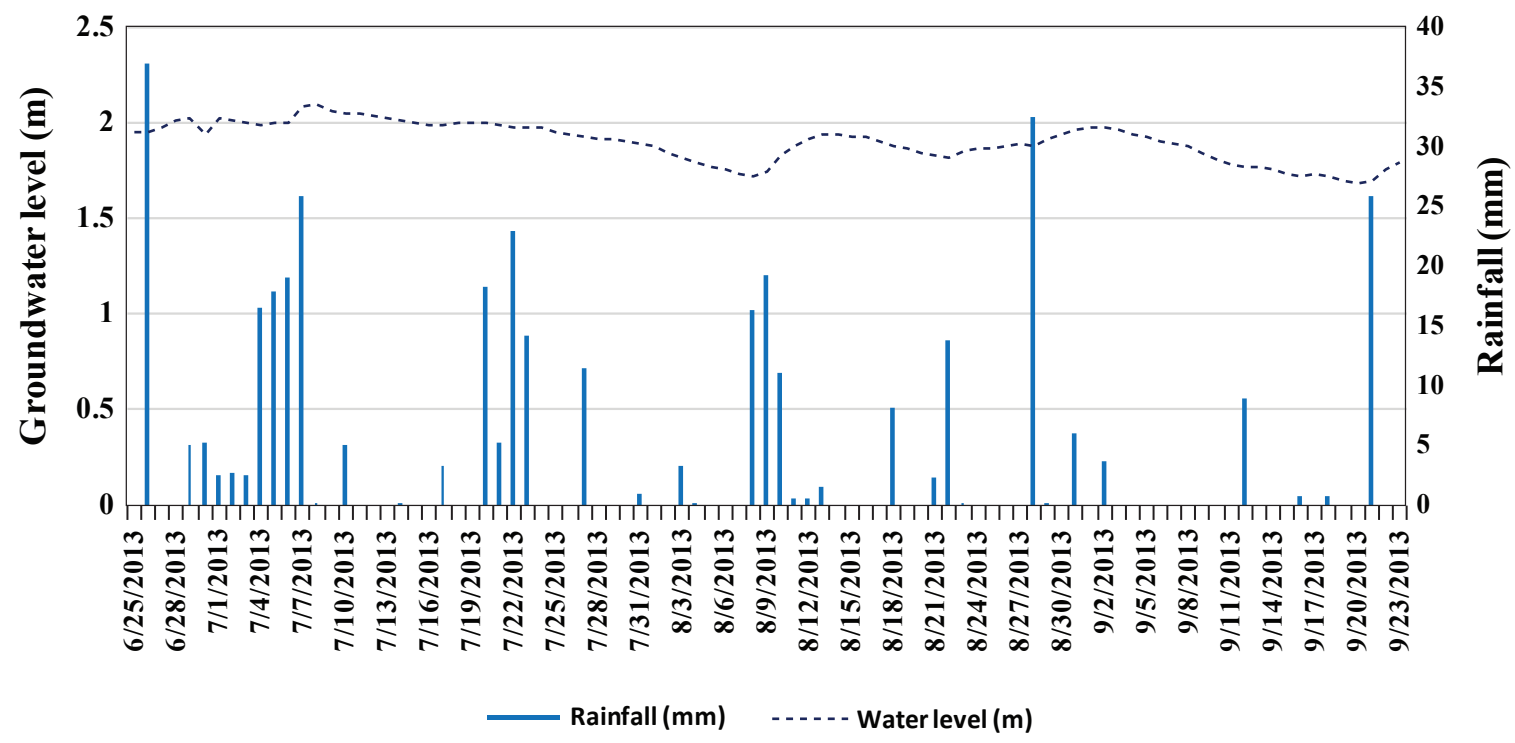

Figure 5. Maximum daily groundwater levels measured from the pressure recorder in borehole B1 compared with daily rainfall from June 25 through September 23, 2013. Groundwater level increased after rainfall events. 
Readings were taken once a week for the first 2 mo and once a month after that. Cumulative horizontal displacement in B1 in the head of the landslide through May 20, 2014, was approximately 2 $\mathrm{cm}$. Cumulative displacement in B3 near the toe of the landslide through May 20, 2014, was approximately $5 \mathrm{~cm}$. The greatest average velocity in B1 (0.05 mm/d) occurred from June 11 to July 2, 2013. This interval corresponded with $78.7 \mathrm{~mm}$ of rainfall and had the second highest daily total during monitoring, $36.8 \mathrm{~mm}$ on June 26 . The two greatest average velocity increases in B3 were $0.16 \mathrm{~mm} / \mathrm{d}$ from April 19 to May 8, 2013, and $0.5 \mathrm{~mm} / \mathrm{d}$ from April 19 to May 20, 2014. These intervals corresponded with 46.9 and $130.7 \mathrm{~mm}$ of rainfall, respectively. Although the inclinometer measured little movement, landslide movement and rainfall events were correlated (Fig. 6).

Generally, the increase in movement in B3 in spring 2013 and spring 2014 correlated with the obvious pulses of rainfall. During the summer months, pulses of rain triggered most of the movement in B1. Movement increased significantly in April and May 2014, backed up by more rainfall in these months $(166.5 \mathrm{~mm})$ than in $2013(92.2 \mathrm{~mm})$. So that seasonal patterns in movement can be observed, monitoring should extend beyond the 14 months of data presented here. Cumulative and in- cremental inclinometer data from boreholes B1 and B3 are provided in Appendix 2.

Total Station. Surface displacement was monitored at various locations on the landslide using a total station to supplement subsurface displacement information from the inclinometer. Eight survey monuments were secured with concrete approximately $0.45 \mathrm{~m}$ into the ground and leveled. The monuments were distributed along the landslide's longitudinal axis from near the main scarp down to the toe (Fig. 7). The inherent accuracy of total-station surveying allows small amounts of movement to be detected even before cracking or tension scarps are apparent.

A relative coordinate system was created using the monuments and two known reference base points outside the slide area assumed to be stable. These points were above the head scarp and located on structures that appeared not to have moved. We designated one of the reference points as the origin of the coordinate system so that the monuments could be rotated, georeferenced with true north, and plotted on an aerial photograph. Measurements were calculated once a month starting May 1, 2013, and ending November 13, 2013. Displacements were measured using the differences in easting, northing, and height from the startingdate measurements. This allowed displacement of

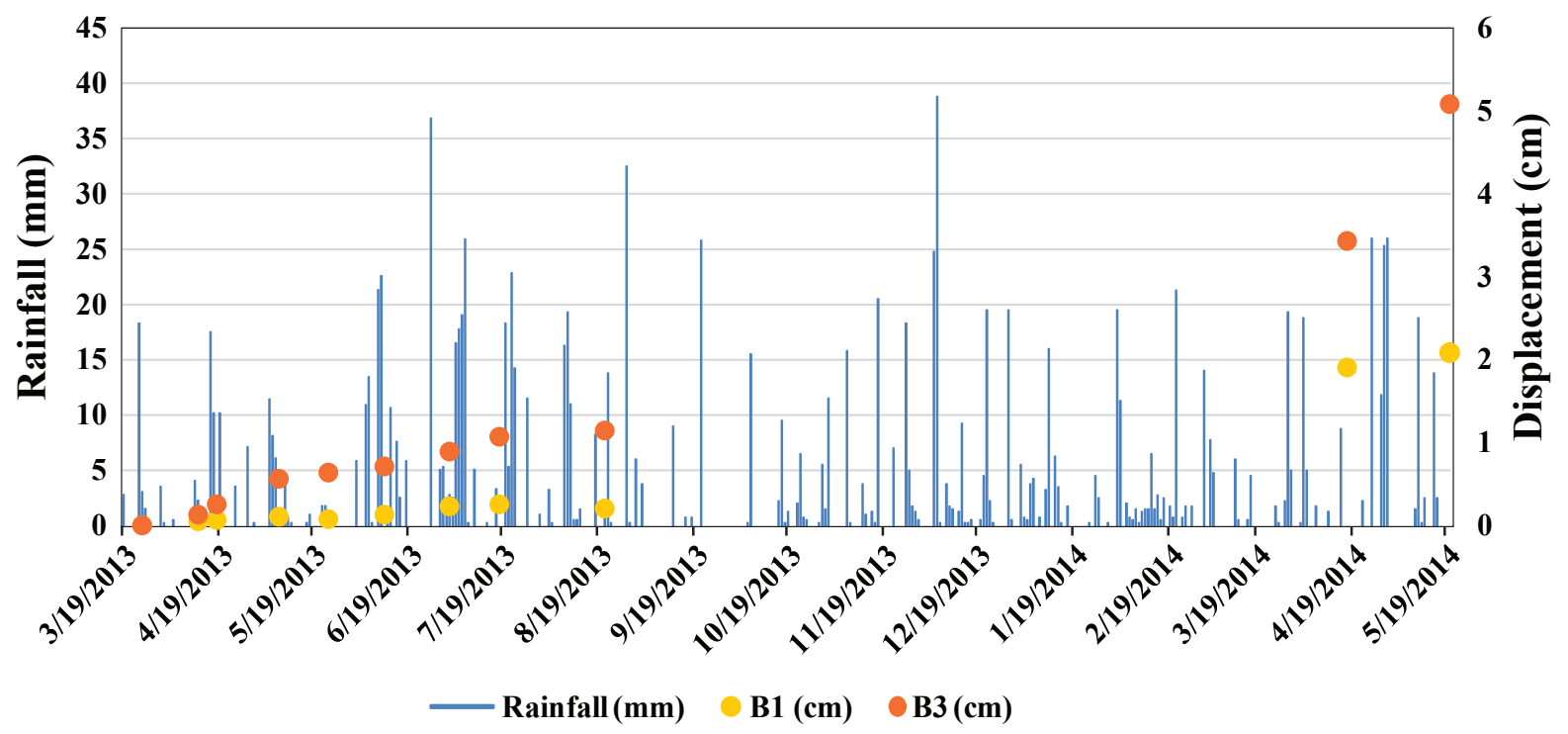

Figure 6. Inclinometer displacement versus time in boreholes B1 and B3, plotted with rainfall. From June 11 to July 2, 2013 , a high frequency of rainfall occurred, resulting in highest average velocity displacement during the study. Rainfall from June 11 to July 2, 2013, totaled $78.7 \mathrm{~mm}$ and included the second highest daily rainfall amount of $36.8 \mathrm{~mm}$ on June 26 . 


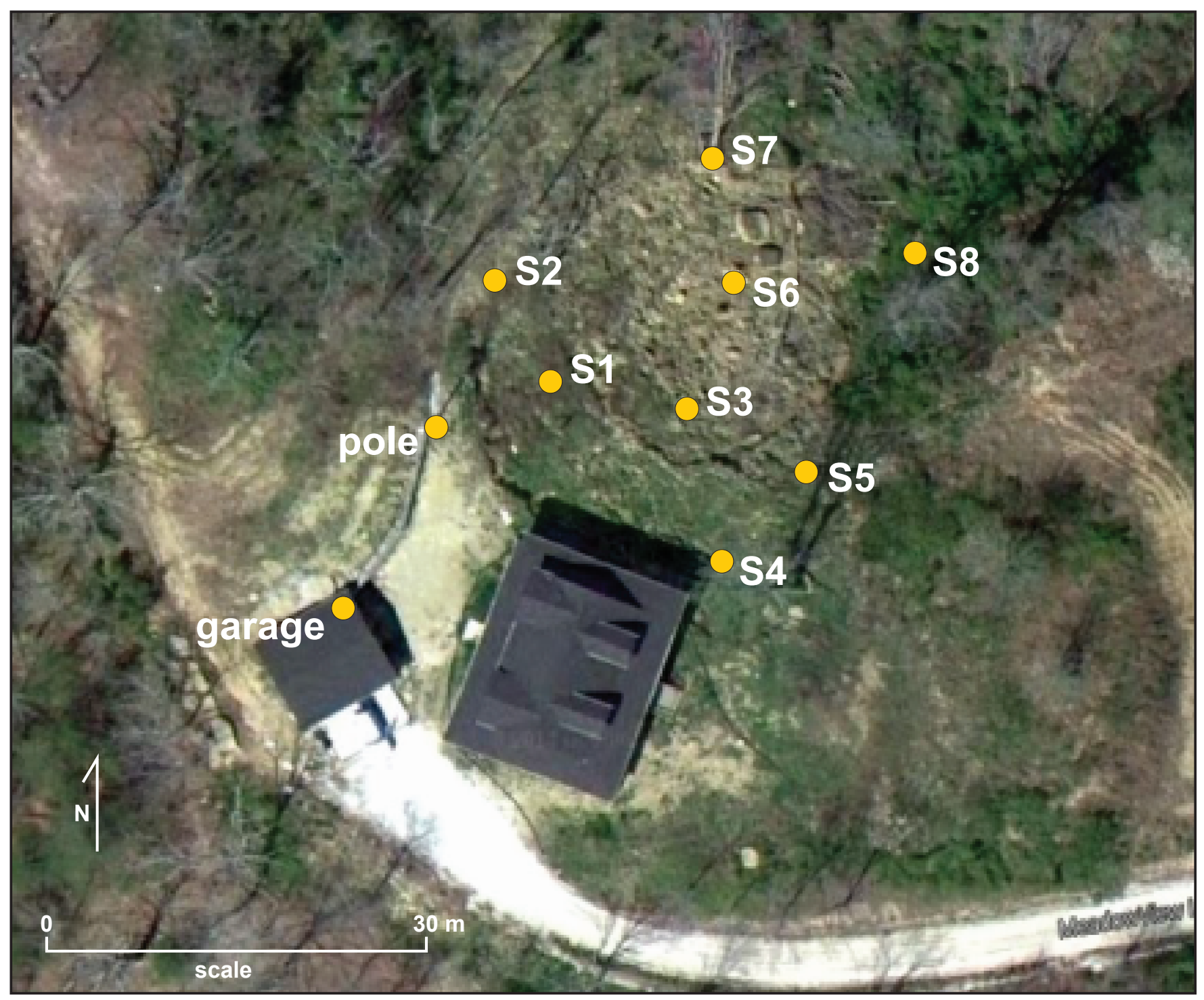

Figure 7. Locations of total station monuments.

each stake to be monitored over time, as well as the overall average stake displacement over time. The general direction of movement is to the northeast, which corresponds to the general slope direction and movement of material. Monuments S3, S5, S6, and 58 moved in the expected direction, trending generally northeast (Figs. 8-9). Except for S8, these monuments moved horizontally a total of $5.8 \mathrm{~cm}$. S8 had horizontal displacement of approximately $3.74 \mathrm{~cm}$ in the northeast direction. S8 is at the toe where the landslide flows, and more subsurface displacement was measured with the inclinometer.

Not all monuments moved in the expected direction, and several had little downslope movement, which was not discernable from the mini- mum resolvable distance threshold of the total station (approximately $5 \mathrm{~mm}$ ); thus, the general direction was not determined. Several points appeared to move upslope, however, located on the slump block or at a hinge and showed no movement. S7, for example, showed backward movement and movement over time that generally trended southeast. This is reasonable, because S7 lies near the flank of the landslide that faces southeast and may have undergone initial rotational movement on the steep flank of the slide. The monuments that moved downslope were all in the lower part of the landslide, below the secondary scarp, where the translational flow is occurring. The relatively small horizontal movement of the 


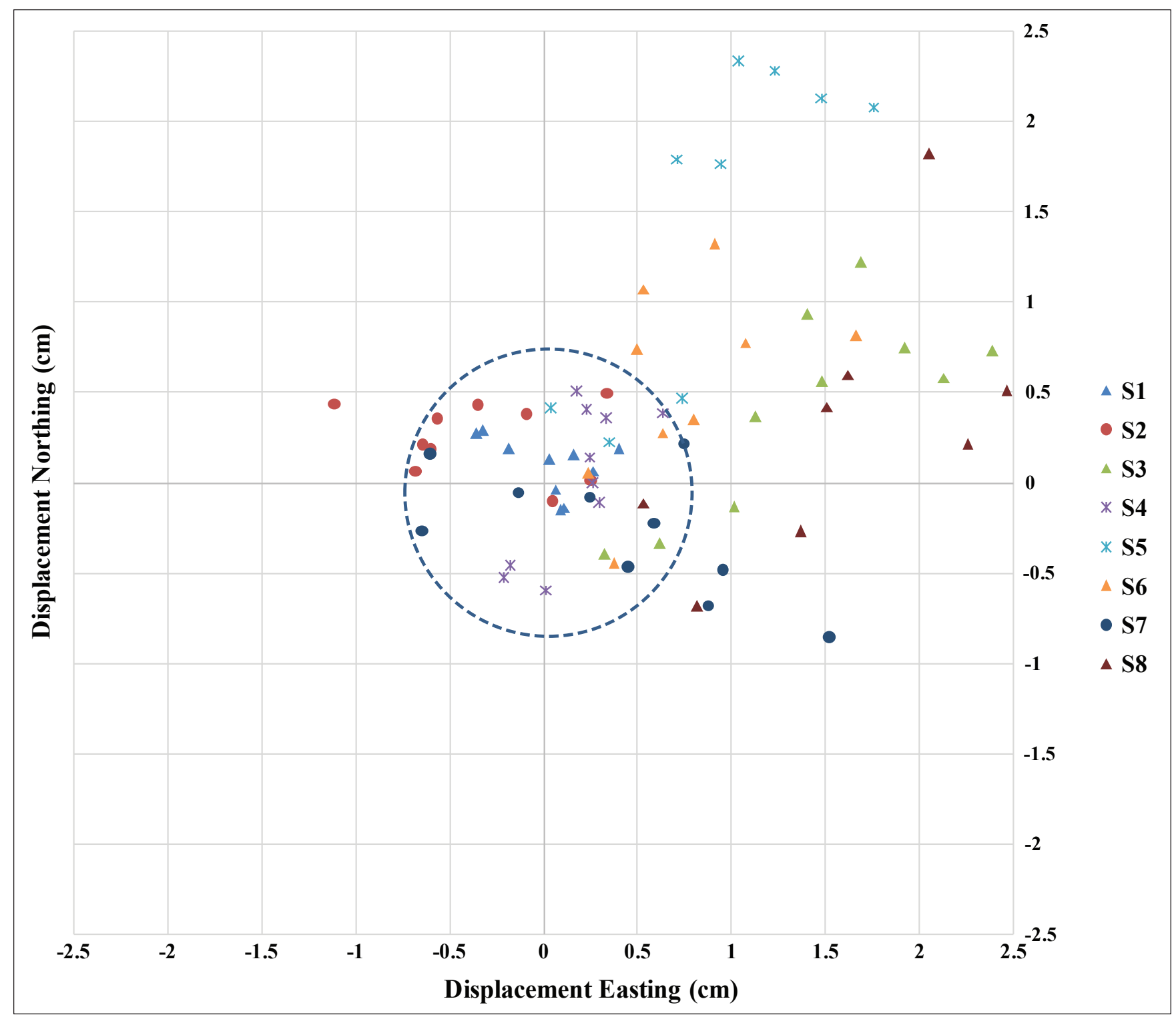

Figure 8. Georeferenced coordinate system showing surface displacement of all eight monuments in the Meadowview landslide. The general trend of movement is downslope, toward the northeast. Monuments in the area indicated by the dashed circle show approximate area of little discernable movement or movement backward from rotation.

monuments agrees with the small subsurface horizontal offset measured by the inclinometer.

\section{Electrical Resistivity}

The technique of 2-D electrical resistivity has been proven successful for imaging many different types of landslides in order to detect slide planes, lithologic interfaces, and moisture regimes (Brooke, 1973; Bogoslovsky and Ogilvy, 1977; McCann and Forster, 1990; Godio and Bottino, 2001; Bichler and others, 2004; Lapenna and others, 2005; Drahor and others, 2006; Sastry and others, 2006; Jongmans and Garambois, 2007; Perrone and others, 2008; Sass and others, 2008; Schrott and Sass, 2008; de Bari and others, 2011; Travelletti and others, 2012; Van Dam, 2012). We measured electrical resistivity six times and borehole resistivity twice at two different times of the year (Fig. 10). The borehole and surface measurements were initially conducted on separate dates on June 14 and July 26, 2013, respectively, and both repeated on November 13, 2013. The surface measurements were set up as two arrays perpendicular to the slope direction and one array parallel to the slope direction, down the axis 


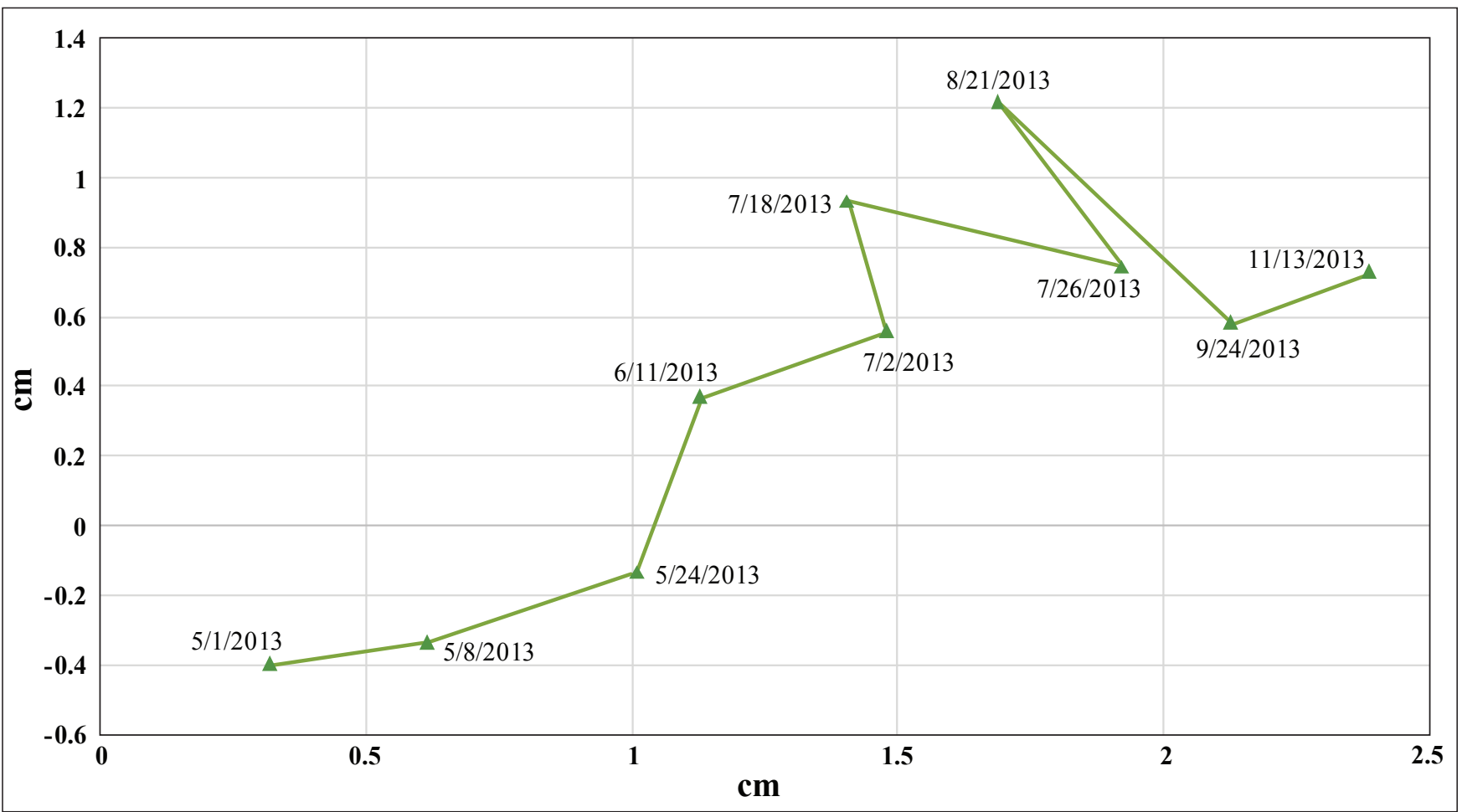

Figure 9. Movement of total station monument S3 over time. The general direction of movement is to the northeast.

of the landslide, using an eight-channel resistivity meter. The surface arrays used a dipole-dipole electrode configuration with 1.5-m electrode spacing. Short spacing allows for higher resolution and is optimal for landslides anticipated to be shallow (less than $10 \mathrm{~m}$ ). The dipole-dipole array has been proven to be successful for obtaining higher-resolution data and determining shallow interfaces in landslides (Lapenna and others, 2005; Schrott and Sass, 2008).

The borehole measurements were made in B5 and B6, the slotted PVC boreholes, and used a cross-hole method that measured voltage between electrodes. We used borehole electrodes at $0.5-\mathrm{m}$ intervals. The boreholes were spaced $7.1 \mathrm{~m}$ apart and were $5 \mathrm{~m}$ deep, so as to have an aspect ratio (depth of hole/distance between holes) close to 1.5 , to maximize resolution (Advanced Geosciences Inc., 2003). The cables hung in the two open boreholes. The electrodes had to be in direct contact with the soil (as with the surface arrays), so the PVC was filled with water to transmit the current to the soil. The boreholes were aligned with surface array MVS1, which is parallel to the downslope direction of the slide. This allowed comparison with the surface electrical-resistivity tomography im- ages of MVS1 and MVS2, which was arranged perpendicular to the downslope direction.

\section{Resistivity Results}

Layering and clear resistivity contrasts show that high and low zones are present in the inverted images and reflect the shallow landslide geometry and both rotational and translational style of movement. Because electrical-resistivity surveys measure the potential difference of voltage injected into a nonhomogenous (and anisotropic) subsurface, the data must be inverted to reconstruct the subsurface resistivity from measured and modeled voltage data. This is called inversion, and helps to create the image profiles used to interpret the subsurface. Interpreted surfaces coincide with sharp drops in resistivity, indicating high water content (perched water) or possibly higher clay content. These zones, including the failure surface, correlate with lithologies observed in the boreholes, measured moisture content, and landslide depth determined from the two inclinometers. The surface and borehole arrays show ranges of electrical-resistivity values that are generally the same with all profiles, and the ranges do not vary significantly between the two different measurement dates. Very 


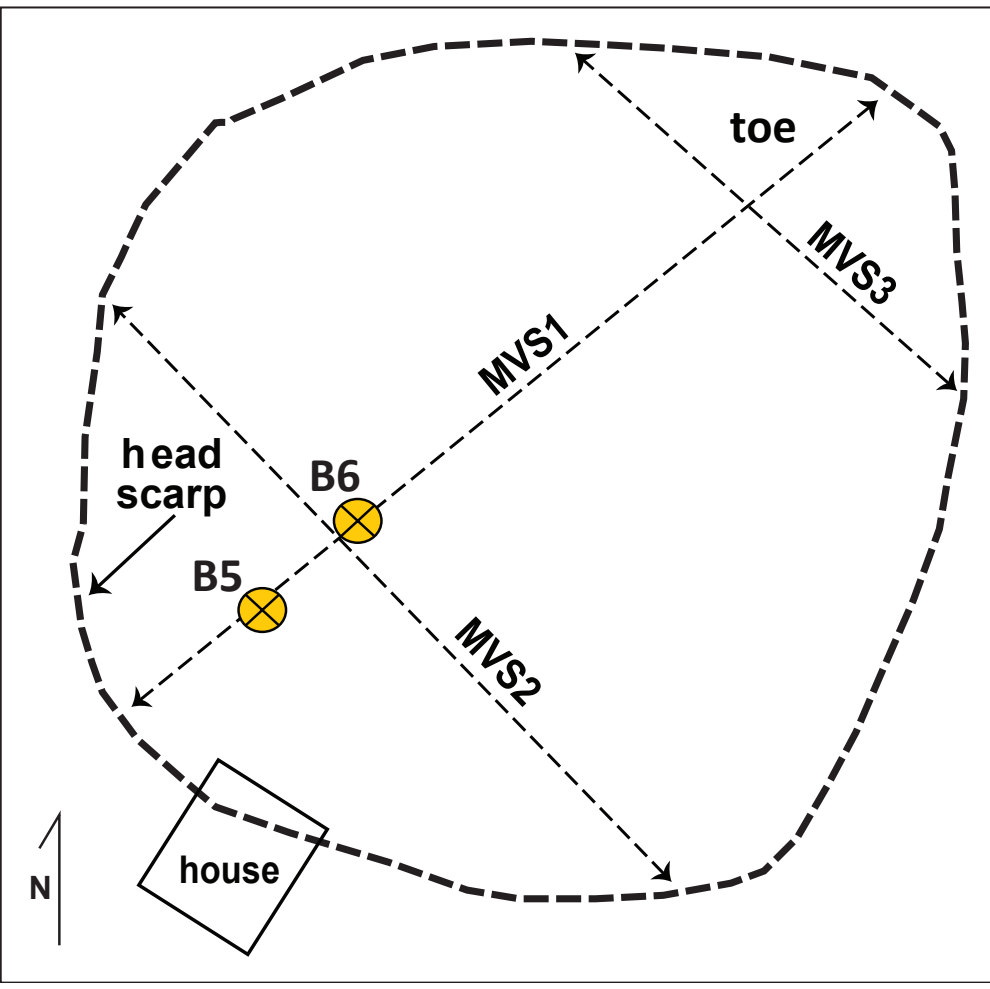

Figure 10. Electrical-resistivity array locations in the Meadowview landslide.

little precipitation had fallen in the 2 days leading up to all the measurements, and little groundwater fluctuation occurred in piezometer B2. Overall precipitation amounts were less in the fall than in the summer, which may account for slight differences in the inverted imagery.

\section{Example Inverted Resistivity Sections}

MVS1, 7/26/2013: Parallel to the landslide axis in the downslope direction-MVS1 spans $45.7 \mathrm{~m}$ and extends downslope from the crown of the slide to the toe (Fig. 11). The inverted resistivity section shows that distinct layering and contrasts in resistivity are evident near the head scarp of the slide. A semi- continuous high-resistivity layer (oranges to reds) is present near the surface, ranging between approximately 50 and $600 \Omega-\mathrm{m}$. An identifiable break in the high-resistivity layer occurs at the surface at the head scarp displacement. A thin, lower-resistivity zone (greens) appears below the high-resistivity layer, ranging from 30 to $50 \Omega-\mathrm{m}$. Perched water on the underlying clay shales creates the lower resistivity (higher conductivity) values. This zone continues downslope, occurring near the surface where water intersects the surface seeps near the toe of the landslide. A patchy low-resistivity zone (blues) occurs below the high-resistivity zone, approximately $2.7 \mathrm{~m}$ below the surface in the head of the landslide. This lowresistivity zone ranges from approximately 8 to $19 \Omega-\mathrm{m}$. Starting at the head scarp, this low-resistivity zone extends downslope for about $22 \mathrm{~m}$ and has an undulating, arcuate shape. It becomes shallower farther downslope and ends abruptly. We interpreted this zone as the failure surface; this was confirmed by inclinometer data that indicated the failure surface's depth at B1 to be about $2.7 \mathrm{~m}$. Below the low-resistivity zone, resistivity increased to a range of approximately 30 to $50 \Omega$-m (greens) down to the bottom of the section.

To get a closer look at the resistivity data, we extracted resistivity and depth $(x, y$, and $z)$ from the raw inverted resistivity data at the location of borehole B1. These data are shown in a resistivity profile through the high- and low-resistivity layers near the head scarp (Fig. 12). The sharp peak of a resistivity increase at a depth of $1 \mathrm{~m}$ to about $128 \Omega$-m correlates to the lithologic change in the disturbed colluvial fill. This material grades from

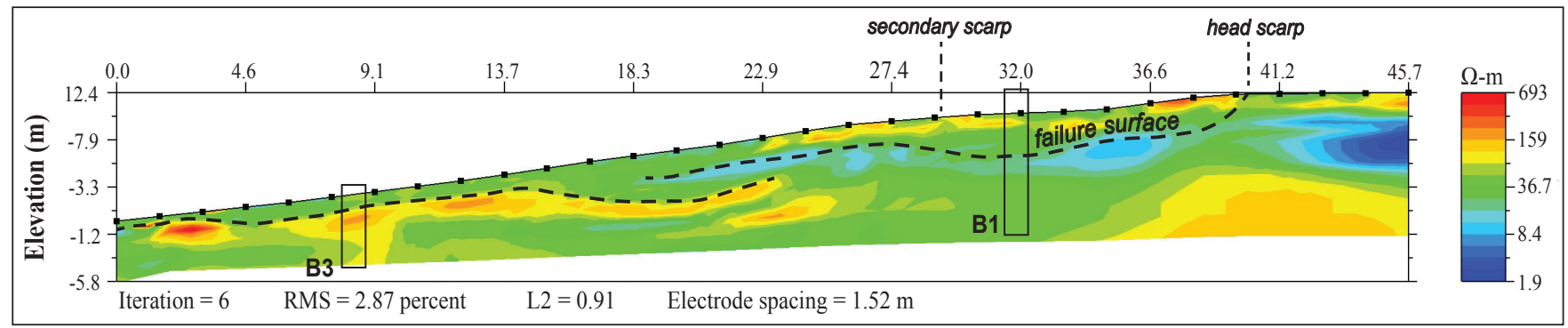

Figure 11. Inverted electrical-resistivity array MVS1. Dashed lines represent multiple failure surfaces. Locations of boreholes, the head scarp, and secondary scarp are shown. 
a sandy lean clay into a moderately stiff, sandy fat clay. There was also a big jump in density at this interface, as shown by the blow counts in the lithologic logs. Water was encountered during drilling at this interval, at about $1.2 \mathrm{~m}$. Resistivity then decreased (moisture content increased) to approximately $19 \Omega-\mathrm{m}$. This interval and the lowresistivity peak correlate with the contact between high-moisture conditions at the colluvial fill and very stiff, fat clay shale, which is also the inferred failure surface. Below the inferred failure surface, the resistivity increased slightly as the moisture content decreased.

Midslope, approximately $17.3 \mathrm{~m}$ downslope from the head scarp, resistivity ranged between 14 and $19 \Omega-\mathrm{m}$ in the low-resistivity zone that is the interpreted failure surface. Below the failure surface, resistivity increased toward two distinct high-resistivity zones. One is a continuous arcuate zone that continues downslope; the other deeper zone is lenticular shaped. These may be the deeper, drier(?) clay-shale layers (less conductive). These high-resistivity zones ranged between approximately 80 and $160 \Omega-\mathrm{m}$. No borehole was drilled midslope, but the interpreted failure surface (lowresistivity peak) from the resistivity profile from MVS1 (Fig. 13) correlates with the failure surface determined from the inclinometer data.
Toward the toe (Fig. 11), the distinct resistivity zones became more complex. Extracted resistivity and depth data $(x, y$, and $z)$ from the raw inverted-resistivity profiles at the location of borehole B3 showed a high-resistivity peak of $79 \Omega-\mathrm{m}$ just below the surface. At B3, the colluvial fill was only $0.6 \mathrm{~m}$ deep, supporting the shallow flow type of slope movement at the toe. The failure surface was difficult to identify in the inverted-resistivity section's correlation to the borehole data. The inclinometer data from borehole B3 indicated that the failure surface was 1.2 to $1.5 \mathrm{~m}$ below the surface. The underlying high-resistivity layer (curved yellow layers and orange layer that start midslope) was approximately 90 to $130 \Omega-m$ and correlates to the lean clay-clay shale contact where a stiff, structured lean clay transitions to a very soft, weathered clay shale. A distinct low-resistivity peak of approximately $50 \Omega$-m occurred about $4.3 \mathrm{~m}$ below the surface, which correlates with the clayey shaleshale contact and a decreasing moisture content, as described in the borehole. A high-resolution, lenticular zone was present at the end of the MVS1 array. This zone was approximately $2 \mathrm{~m}$ in length and had significantly higher resistivity values than the continuous high-resistivity zone that started midslope and curved toward the toe. This feature could be a large sandstone boulder that was dislodged during excavation of the house foundation.

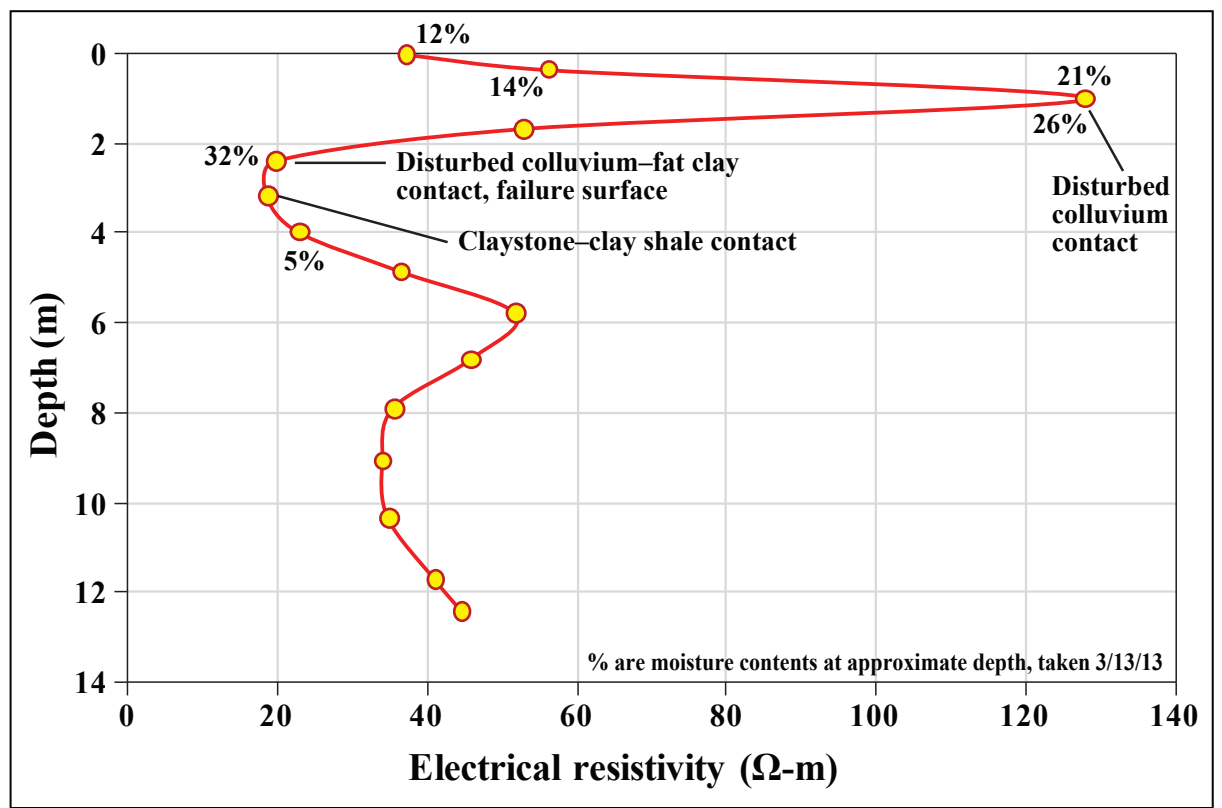

Figure 12. Vertical electrical-resistivity profile at borehole B1. Depth starts at the first point, toward the top of the curve, which is at the surface.
Large boulders of that size, up to $1.5 \mathrm{~m}$ in length, were identified in the field, at the toe of the slide.

MVS2, 7/26/2013: Perpendicular to the downslope direction, upper slope - Electrical-resistivity array MVS2 spanned $36.6 \mathrm{~m}$ perpendicular to the downslope direction along the upper part of the slide. This array crosses borehole B1 (Fig. 14). There was a clear contrast between a higher-resistivity zone and an underlying low-resistivity zone. We interpreted this boundary to be the failure surface, which corresponds with the colluvial fill and fat clay 


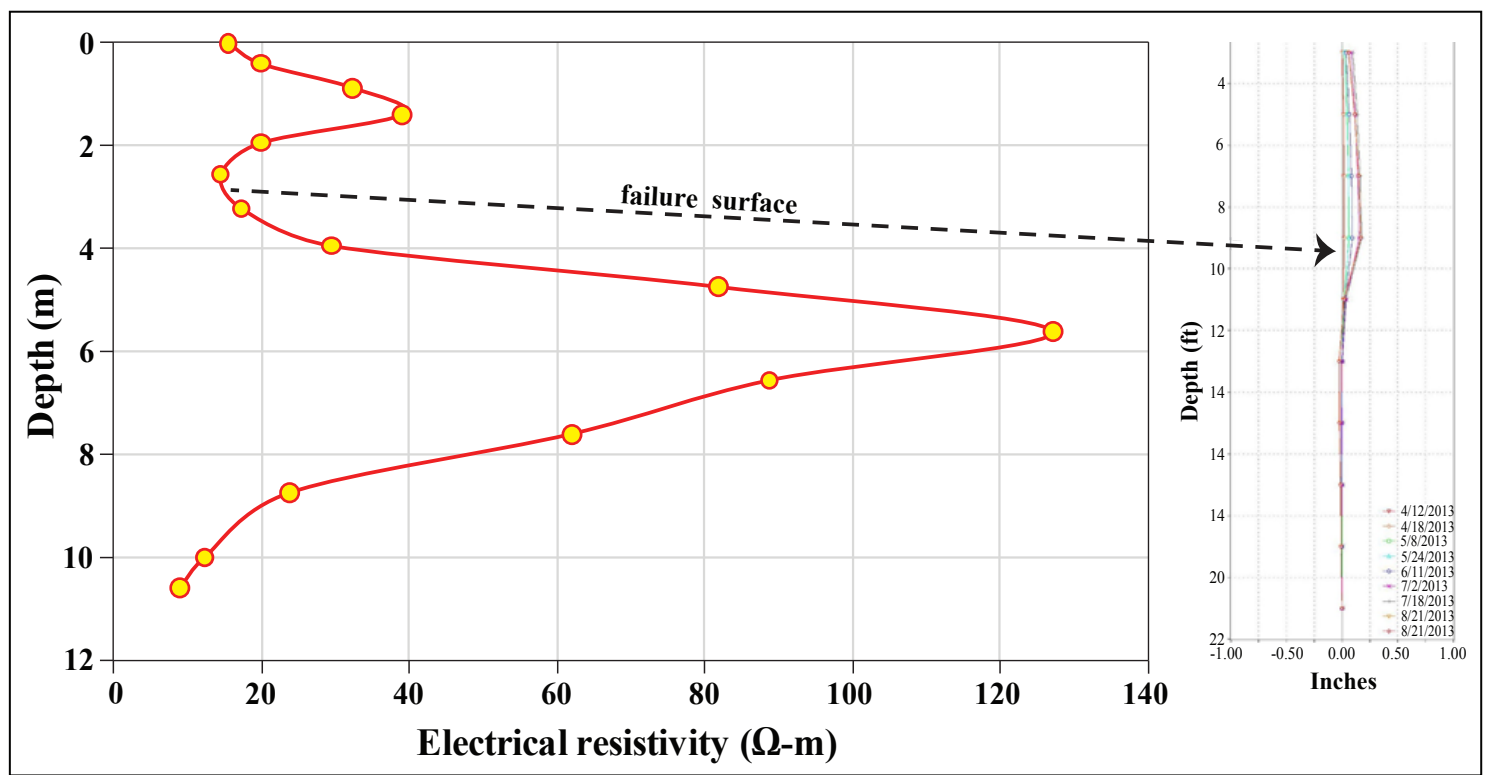

Figure 13. Vertical-resistivity profile taken midslope from section MVS1. The low-resistivity peak correlates with the failure surface depth measured with the inclinometer. Depth starts at the first point, toward the top of the curve, which is at the surface. Values on the inclinometer reading are depth in feet.

bedrock contact, and the landslide depth indicated in the inclinometer data from borehole B1. Two lenticular-shaped high-resistivity zones (possibly connected) occupied the right side of the inverted section above the failure surface. The right side of the section (toward the end) runs northwest, leading toward the head scarp. A moderately thick (approximately 1 to $1.5 \mathrm{~m}$ ) sandstone layer crops out behind the head scarp, and MVS2 may be intersecting this high-resistivity layer.

Resistivity at this location and along the identified failure surface ranged between approximately 20 and $30 \Omega-m$. Similarly to MVS1, a highresistivity peak from $\mathrm{x}, \mathrm{y}, \mathrm{z}$ data extracted at the $\mathrm{B} 1$ location correlates to the contact between colluvial fill types, sandy lean clay, and sandy fat clay. The highest moisture content along the B1 transect was measured at a low-resistivity peak, supporting the location of the failure surface.
MVS3, 7/26/2013: Perpendicular to the downslope direction, toe slope - Electrical-resistivity array MVS3 spans $24.4 \mathrm{~m}$ in a transverse direction across the toe of the slide. The inverted section shows a complex pattern of resistivity zones (Fig. 15). An undulating low-resistivity zone was present near the surface. This zone ranged from approximately 24 to $50 \Omega-\mathrm{m}$. This low-resistivity zone transitioned to a high-resistivity zone with lenticular regions. The undulating boundary between the low- and high-resistivity zones for MVS3 was shallow, about $0.6 \mathrm{~m}$ deep, and correlates to the contact between sandy lean clay with gravel fill and stiff, residual, lean clay. The inclinometer measurements from borehole B3 indicate the failure surface is below the colluvial fill-lean clay contact; therefore, the failure zone at the toe may also include the lean clay unit.

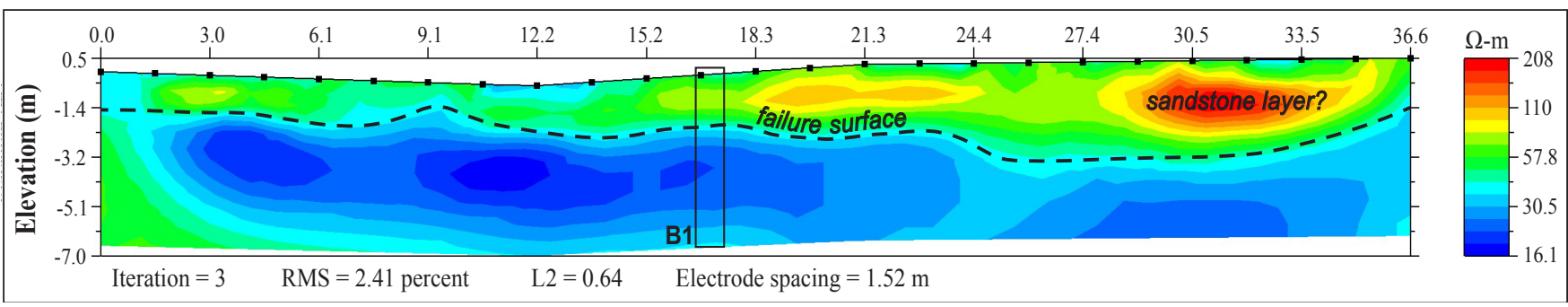

Figure 14. Inverted-resistivity profile MVS2 in a transverse direction, below the head scarp of the landslide. 


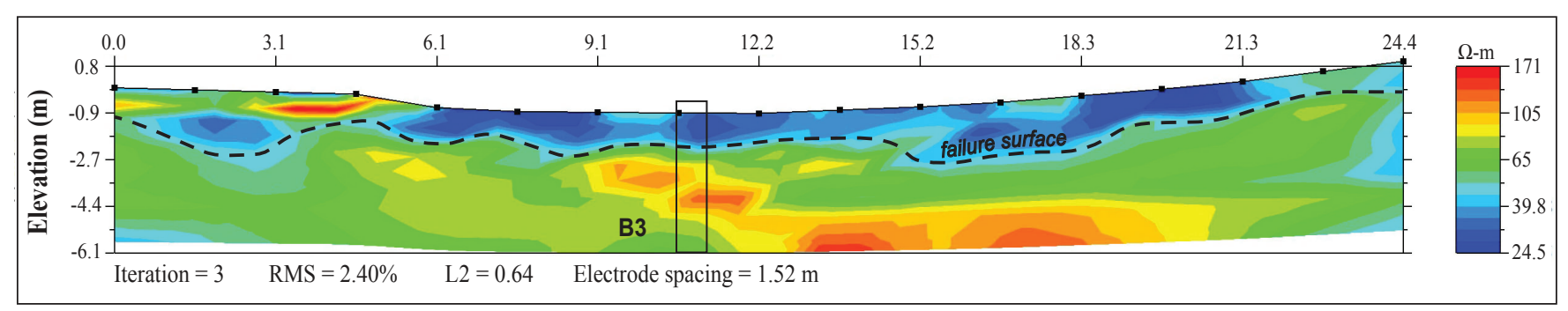

Figure 15. Inverted-resistivity profile MVS3 perpendicular to the downslope direction, along the toe of the landslide.

\section{November Results}

On November 13, 2013, arrays with the same starting and ending points used for the July arrays were laid out and the electrical resistivity was measured. In general, the resistivity contrasts, interpreted features, and correlations to stratigraphic boundaries were similar to what was measured in July (Figs. 16-18). One change in MVS1 was the presence of a low-resistivity zone $(8-26 \Omega-m)$ that extended down vertically below the inferred failure surface, just in front of the head scarp (Fig. 16). This zone accentuated the rotational movement in the head. More water may have infiltrated this area, causing the low-resistivity zone. For MVS3 (November measurement), the measurements from the high-resistivity zones (24-50 $\Omega-\mathrm{m})$ were larger and spaced differently than the measurements from the July inverted section. Approximately $104 \mathrm{~mm}$ less rainfall was measured in the month preceding the November resistivity measurements. This could account for the increased area of higher resistivity in MVS3.

\section{Borehole Resistivity}

A cross-hole method was used to measure resistivity. Similarly to the surface dipole-dipole array, this method is designed to measure the voltage between all electrodes that hang down in the boreholes. Figure 19 shows, in the center of the inverted section, a change in resistivity that correlates with a change in material type in borehole B1 (black dashed line). B1 is between the slotted PVC holes (B5 and B6), which are $7.1 \mathrm{~m}$ apart. There was no significant difference between the June 14 and November 11 measurements and resulting inverted profiles. Figure 13 shows the resistivity data at depth taken from the middle of the borehole profile. There is a slight decrease in resistivity that correlates to the failure surface depth.

\section{Discussion}

For discontinuous, variable bedrock lithologies and heterogeneous soils, drilling boreholes may not provide the data needed to interpret the landslide type and failure surface. Geophysical investigations, specifically electrical resistivity, provide an overall view of the subsurface that can supplement drilling and be correlated with soil properties. Geophysical and geotechnical data sets for landslides are primarily independent when seeking to acquire shear strength, however. The challenge is taking a nonunique solution of resistivity measurements in the subsurface and linking those values to mechanical properties that can be used in shear-strength models. Quality subsurface data, including detailed lithologic logs, an idea of

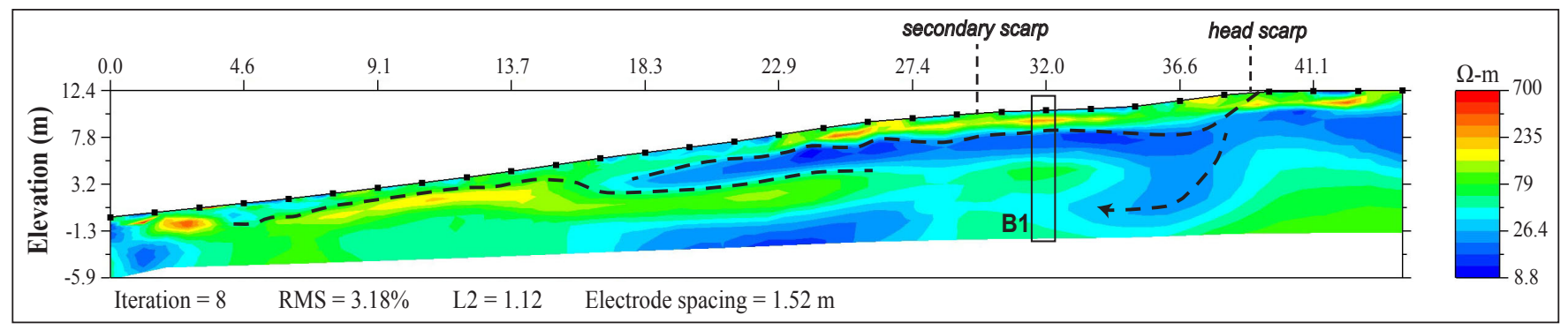

Figure 16. Inverted-electrical-resistivity array MVS1-2, measured in November 2013. Dashed lines represent multiple failure surfaces. Locations of borehole B1, the head scarp, and secondary scarp are shown. 


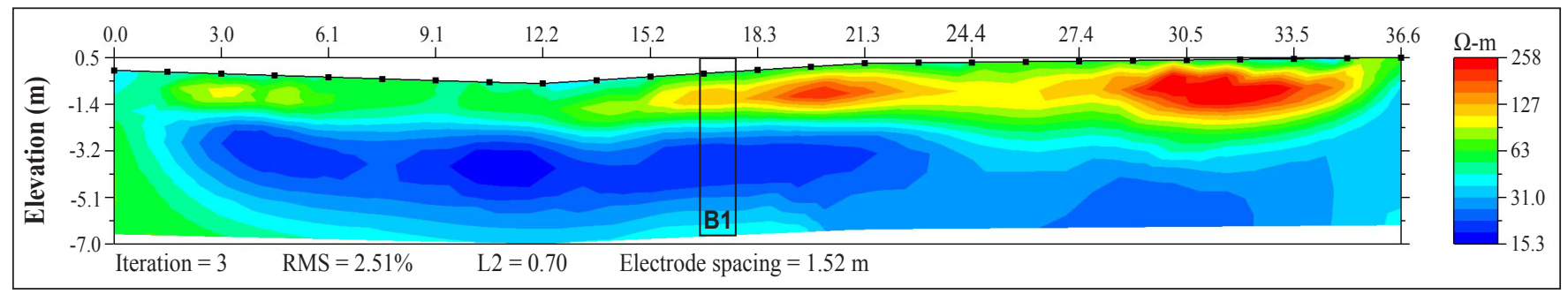

Figure 17. Inverted-electrical-resistivity array MVS2-2, measured in November 2013. Dashed lines represent the failure surface near the head scarp. Location of borehole B1 is shown.

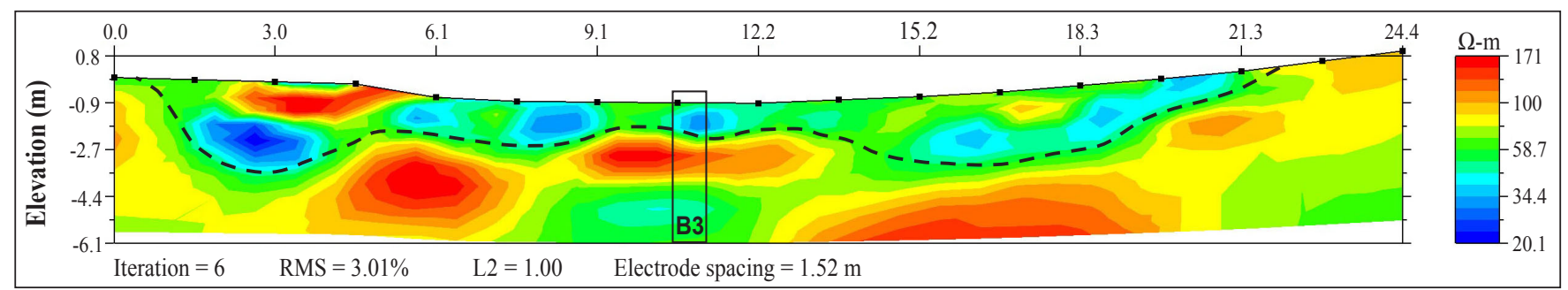

Figure 18. Inverted-electrical-resistivity array MVS3-2, measured in November 2013. Dashed lines represent the failure surface at the toe. Location of borehole B3 is shown. The contrast between the low-resistivity zone and the high-resistivity zone was less conspicuous in November than it was in July.

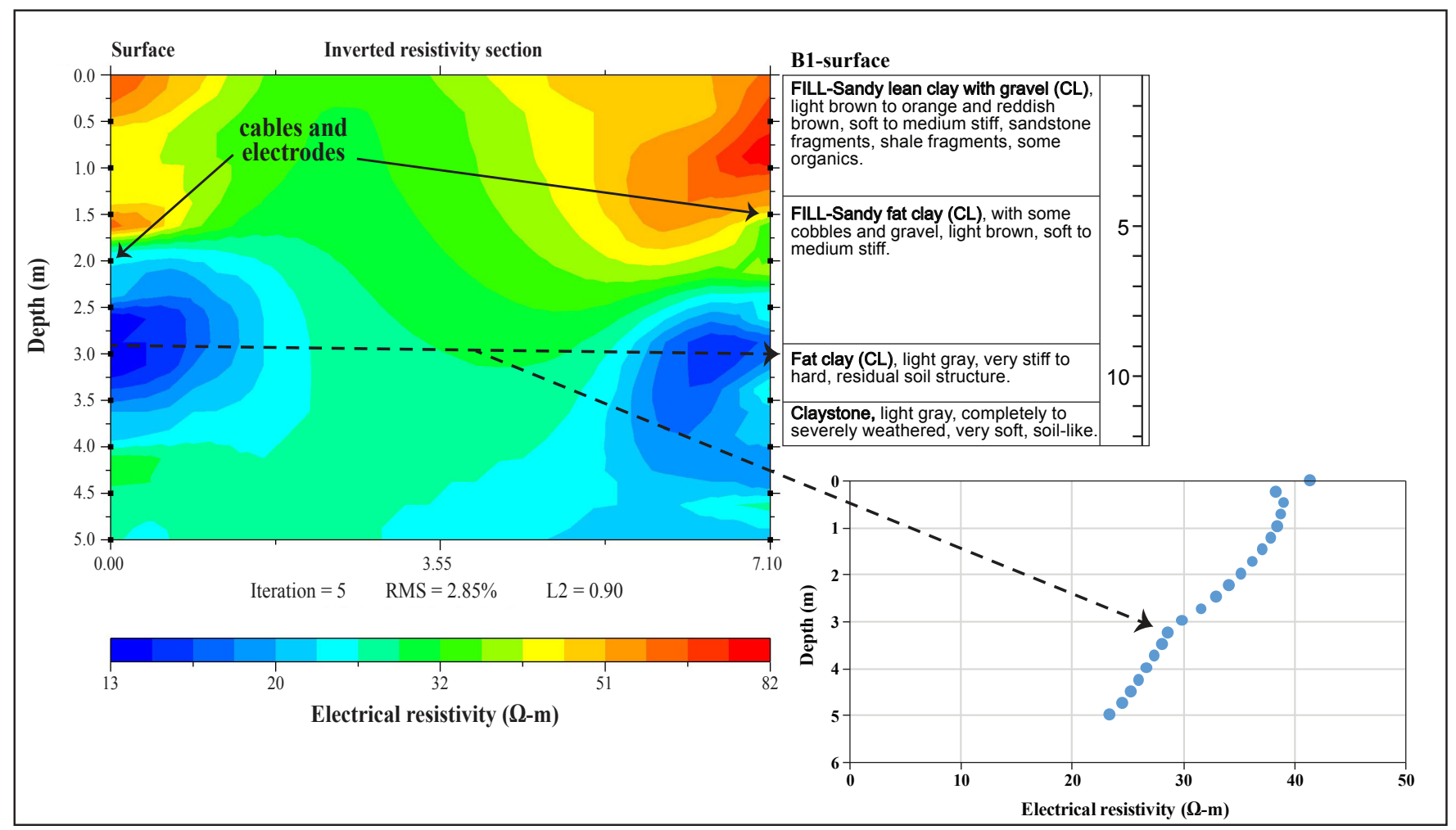

Figure 19. Borehole resistivity results from June 14, 2013. The middle of the inverted section shows a contrast in resistivity that correlates to the colluvial fill-fat clay stratigraphic boundary. 
groundwater flow, and applicable laboratory data, are imperative for using electrical resistivity as a tool for characterizing landslide behavior. Investigations of shallow, colluvial landslides that aim to correlate electrical resistivity with factors needed to calculate shear strength would benefit from having a tool for repetitive stability assessment.

The success of electrical-resistivity measurements to characterize thin, shallow colluvial soils on shallow weathered rock will allow landslidehazard research to be expanded by not only identifying failure planes and moisture regimes, but by relating the electrical-resistivity values to soil properties such as moisture content, matric suction, and porosity that govern slope stability. Although not addressed in this study, the practical application of a better understanding of shallow colluvial landslides is to demonstrate that nonintrusive, repeatable electrical-resistivity measurements can be correlated with soil properties for effective slopestability assessments.

\section{Conclusions}

Traditional geologic and geotechnical data were used to characterize an active shallow colluvial landslide on weathered rock; electrical resistivity was used to help determine the landslide failure plane, stratigraphy, and moisture regimes. Borehole logs provided details of subsurface stratigraphy. Increases in groundwater levels corresponded with particular precipitation events. During the study, total displacement in borehole B1 was $2 \mathrm{~cm}$ and in borehole B2 at the toe, $5 \mathrm{~cm}$. The highest average velocity at B1 occurred between mid-June and early July 2013. During this interval, $78.7 \mathrm{~mm}$ of rain fell, and the second highest daily accumulation during monitoring, $36.8 \mathrm{~mm}$, occurred on June 26. The highest average velocity at B3 occurred from July 2-18, 2013, during which $91.4 \mathrm{~mm}$ of rain fell. The rainfall at the site during the year was approximately $127 \mathrm{~mm}$ less than the average annual rainfall in the region, which may explain why there was only minor movement over the course of the year. The total station measurements of surface movement supplemented the subsurface inclinometer measurements.
The surface electrical-resistivity measurements across the Meadowview landslide resulted in inverted-resistivity sections with distinct resistivity contrasts that correlate to borehole stratigraphy, depth, and groundwater conditions. Lowresistivity zones were indicators of high moisture contents and correlated to the failure surface of the landslide. The inverted-resistivity profiles confirmed the curviplanar and undulating nature and shallow depth of the failure surface indicated by the inclinometer data.

The Meadowview landslide is moving very slowly (Cruden and Varnes, 1996), and although not much movement was observed during the study period, an intense or long-duration rainfall has the capability of triggering future movement. This type of landslide is common in eastern Kentucky, particularly where construction of hillside homes results in slope modifications. Factors contributing to the landslide include the steep slope, weak bedrock, and cut-and-fill slope modification associated with residential development. These conditions occur throughout much of eastern Kentucky, and a better understanding of these types of landslides will aid in landslide hazard analysis.

\section{Acknowledgments}

The Kentucky Geological Survey provided financial support. We would like to thank Terracon Consultants Inc. for drilling and laboratory services, and especially Benjamin Taylor and Christopher Yohe for cooperation and geotechnical advice throughout the project. Francis Ashland of the U.S. Geological Survey Landslide Hazards Program assisted with site selection, technical advice, and editorial review. We would like to thank Zhenming Wang, Mike Lynch, Max Hammond, and Meg Smath at the Kentucky Geological Survey; Ed Woolery at the University of Kentucky Department of Earth and Environmental Sciences for review and technical advice; and Sebastian Bryson at the University of Kentucky Department of Civil Engineering for technical advice. 


\section{References Cited}

Advanced Geosciences Inc., 2003, Cross borehole electrical resistivity tomography (ERT) measurements: www.agiusa.com/datasheets.shtml [accessed 11/12/2014].

Bichler, A., Bobrowsky, P., Best, M., Douma, M., Hunter, J., Calvert, T., and Burns, R., 2004, Three-dimensional mapping of a landslide using a multi-geophysical approach: The Quesnel Forks landslide: Landslides, v. 1, no. 1, p. 29-40.

Bogoslovsky, V.A., and Ogilvy, A.A., 1977, Geophysical methods for the investigation of landslides: Geophysics, v. 42, no. 3, p. 562-571.

Brooke, J.P., 1973, Geophysical investigations of a landslide near San Jose, California: Geoexploration, v. 11, no. 1, p. 61-73.

Community Collaborative Rain, Hail, and Snow Network, 2013, www.cocorahs.org/ ViewData/StationPrecipSummary. aspx [accessed 11/12/2014].

Crawford, M.M., 2012, Understanding landslides in Kentucky: Tools and methods to further landslide hazard research, in Eberhardt, E., Froese, C., Turner, K.A., and Leroueil, S., eds., Landslides and engineered slopes: Proceedings of the 11th International and 2nd North American Symposium on Landslides, Banff, Alberta, Canada, v. 1, p. 467-472.

Crawford, M.M., 2014, Kentucky Geological Survey landslide inventory: From design to application: Kentucky Geological Survey, ser. 12, Information Circular 31, 18 p.

Cruden, D.M., and Varnes, D.J., 1996, Landslide types and processes, in Turner, A.K., and Schuster, R.L., eds., Landslides: Investigation and mitigation: Transportation Research Board, National Research Council, Special Report 247, p. 36-75.

De Bari, C., Lapenna, V., Perrone, A., Puglisi, C., and Sdao, F., 2011, Digital photogrammetric analysis and electrical resistivity tomography for investigating the Picerno landslide (Basilicata region, southern Italy): Geomorphology, v. 133, no. 1, p. 34-46.

Dobrovolny, E., Sharps, J.A., and Ferm, J.C., 1963, Geology of the Ashland quadrangle, KentuckyOhio, and Catlettsburg quadrangle in Ken- tucky: U.S. Geological Survey Geologic Quadrangle Map GQ-196, scale 1:24,000.

Drahor, M.G., Gokturkler, G., Berge, M.A., and Kurtulmus, T.O., 2006, Application of electrical resistivity tomography technique for investigation of landslides: A case from Turkey: Environmental Geology, v. 50, no. 2, p. 147-155.

Godio, A., and Bottino, G., 2001, Electrical and electromagnetic investigation for landslide characterization: Physics and Chemistry of the Earth, Part C: Solar Terrestrial and Planetary Science, v. 26, no. 9, p. 705-710.

Gray, R.E., Ferguson, H.F., and Hamel, J.V., 1979, Slope stability in the Appalachian Plateau, Pennsylvania and West Virginia, USA, in Voight, B., ed., Rockslides and avalanches: New York, Elsevier, v. 2, p. 447-471.

Gray, R.E., and Gardner, G.D., 1977, Processes of colluvial slope development at MC Mechen, West Virginia: Bulletin of Engineering Geology and the Environment, v. 16, no. 1, p. 29-32.

Jongmans, D., and Garambois, S., 2007, Geophysical investigation of landslides: A review: Bulletin de la Société Géologique de France, v. 178, p. 101-112.

Kentucky Mesonet, 2013, Monthly climatological summary: www.kymesonet.org/historical_data. php [accessed 11/12/2014].

Lapenna, V., Lorenzo, P., Perrone, A., Piscitelli, S., Rizzo, E., and Sdao, F., 2005, 2D electrical resistivity imaging of some complex landslides in the Lucanian Appenine chain, southern Italy: Geophysics, v. 70, no. 3, p. B11-B18.

McCann, D.M., and Forster, A., 1990, Reconnaissance geophysical methods in landslide investigations: Engineering Geology, v. 29, no. 1, p. 59-78.

National Climatic Data Center, 2014, Climate data online: 1981-2010: www.ncdc.noaa.gov/cdoweb/datasets [accessed 11/12/2014].

Outerbridge, W.F., 1987a, The Logan Plateau, a young physiographic region in West Virginia, Kentucky, Virginia, and Tennessee: U.S. Geological Survey Bulletin 1620, 19 p.

Outerbridge, W.F., 1987b, Relation between landslides and bedrock in the central Appalachian 
Plateaus, in Schultz, A.P., and Southworth, C.S., eds., Landslides of eastern North America: U.S. Geological Survey Circular 1008, 43 p.

Overfield, B.L., in press, The geologic context of landslide and rockfall maintenance costs in Kentucky - 2002 to 2009: Kentucky Geological Survey, ser. 12, Information Circular.

Perrone, A., Vassallo, R., Lapenna, V., and Caterina, D., 2008, Pore water pressures and slope stability: A joint geophysical and geotechnical analysis: Journal of Geophysics and Engineering, v. 5, no. 3, p. 323-337.

Radbruch-Hall, D.H., Colton, R.B., Davies, W.E., Lucchitta, I., Skipp, B.A., and Varnes, D.J., 1982, Landslide overview map of the conterminous United States: U.S. Geological Survey Professional Paper 1183, 25 p.

Sass, O., Bell, R., and Glade, T., 2008, Comparison of GPR, 2D-resistivity and traditional techniques for the subsurface exploration of the Öschingen landslide, Swabian Alb (Germany): Geomorphology, v. 93, no. 1, p. 89-103.

Sastry, R.G., Mondal, S.K., and Pachauri, A.K., 2006, 2D electrical resistivity tomography of a landslide in Garhwal Himalaya, in Proceedings of 6th International Conference and Exposition on Petroleum Geophysics (Kolkata): Society of Petroleum Geophysicists, India, p. 997-1001.
Schrott, L., and Sass, O., 2008, Application of field geophysics in geomorphology: Advances and limitations exemplified by case studies: Geomorphology, v. 93, no. 1, p. 55-73.

Shakoor, A., and Smithmyer, A.J., 2005, An analysis of storm-induced landslides in colluvial soils overlying mudrock sequences, southeastern Ohio, USA: Engineering Geology, v. 78, no. 3, p. 257-274.

Travelletti, J., Sailhac, P., Malet, J.P., Grandjean, G., and Ponton, J., 2012, Hydrological response of weathered clay-shale slopes: Water infiltration monitoring with time-lapse electrical resistivity tomography: Hydrological Processes, v. 26, no. 14, p. 2106-2119.

Van Dam, R.L., 2012, Landform characterization using geophysics-Recent advances, applications, and emerging tools: Geomorphology, v. 137, no. 1, p. 57-73.

Wieczorek, G.F., and Morgan, B.A., 2008, Debrisflow hazards within the Appalachian Mountains of the eastern United States: U.S. Geological Survey Fact Sheet 2008-3070, 4 p.

Working Party on Worldwide Landslide Inventory, 1990, A suggested method for reporting a landslide: Bulletin of Engineering Geology and the Environment, v. 41, p. 5-12. 


\section{Appendix 1: \\ Log and Laboratory Data}




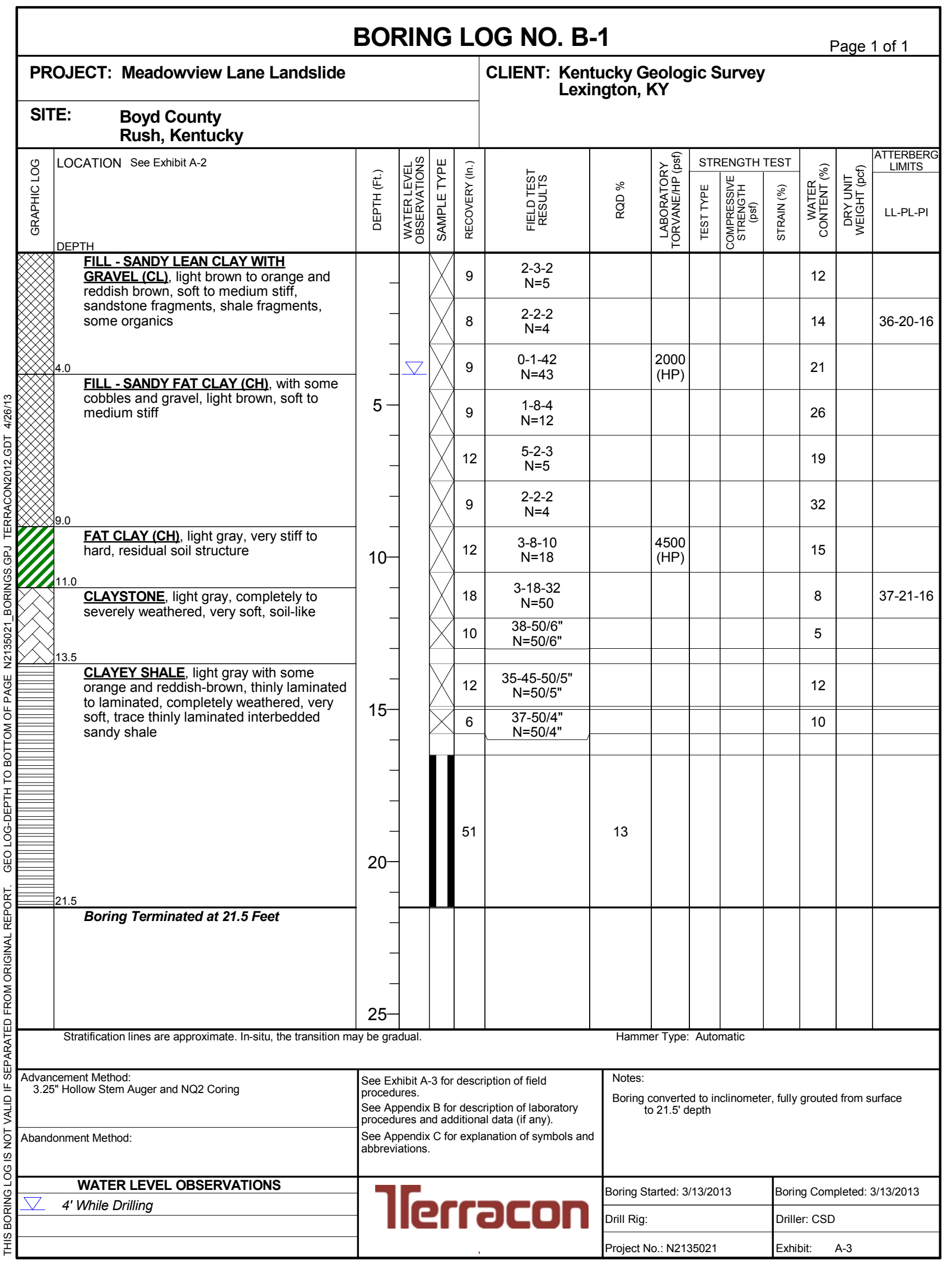




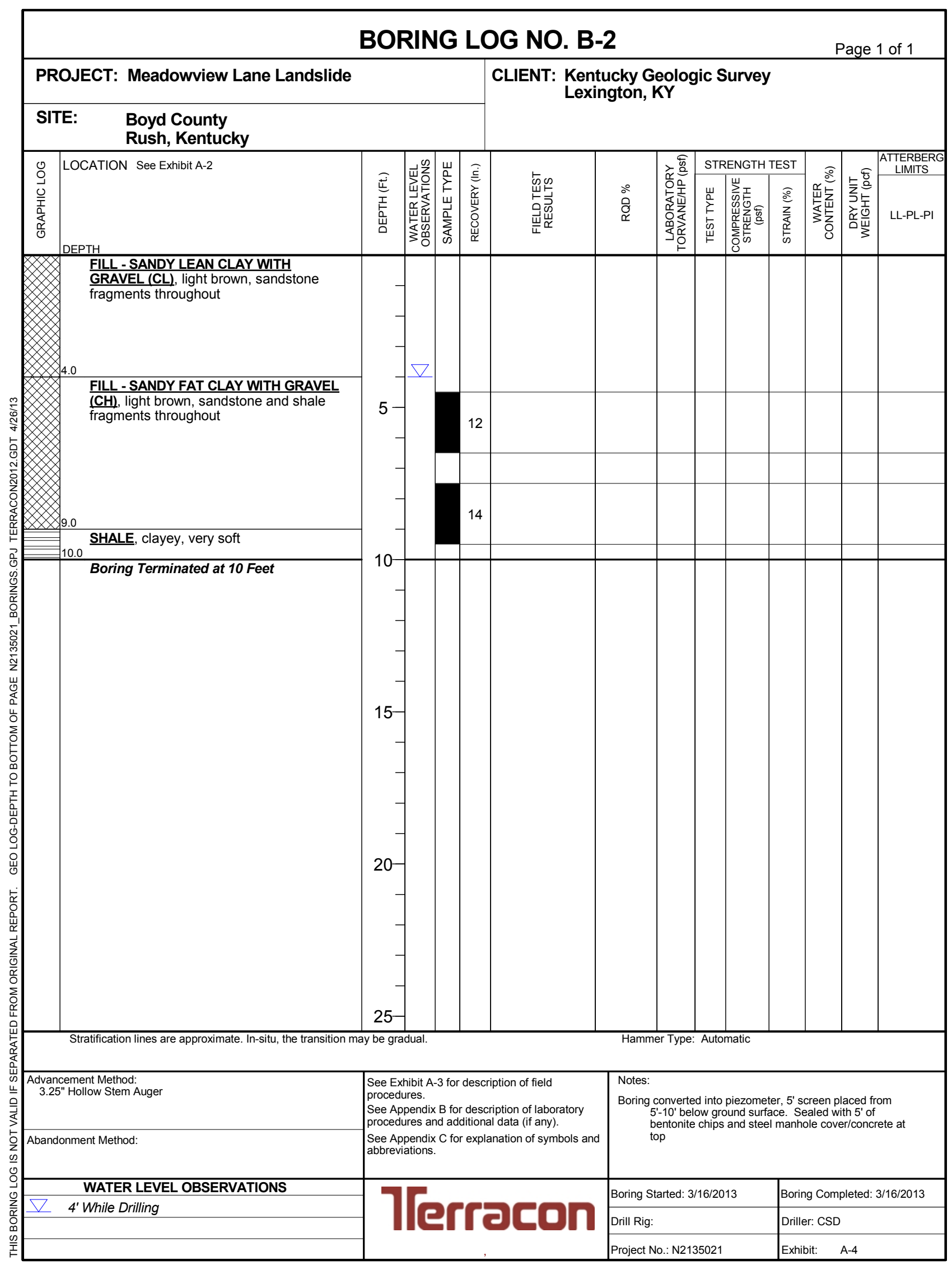




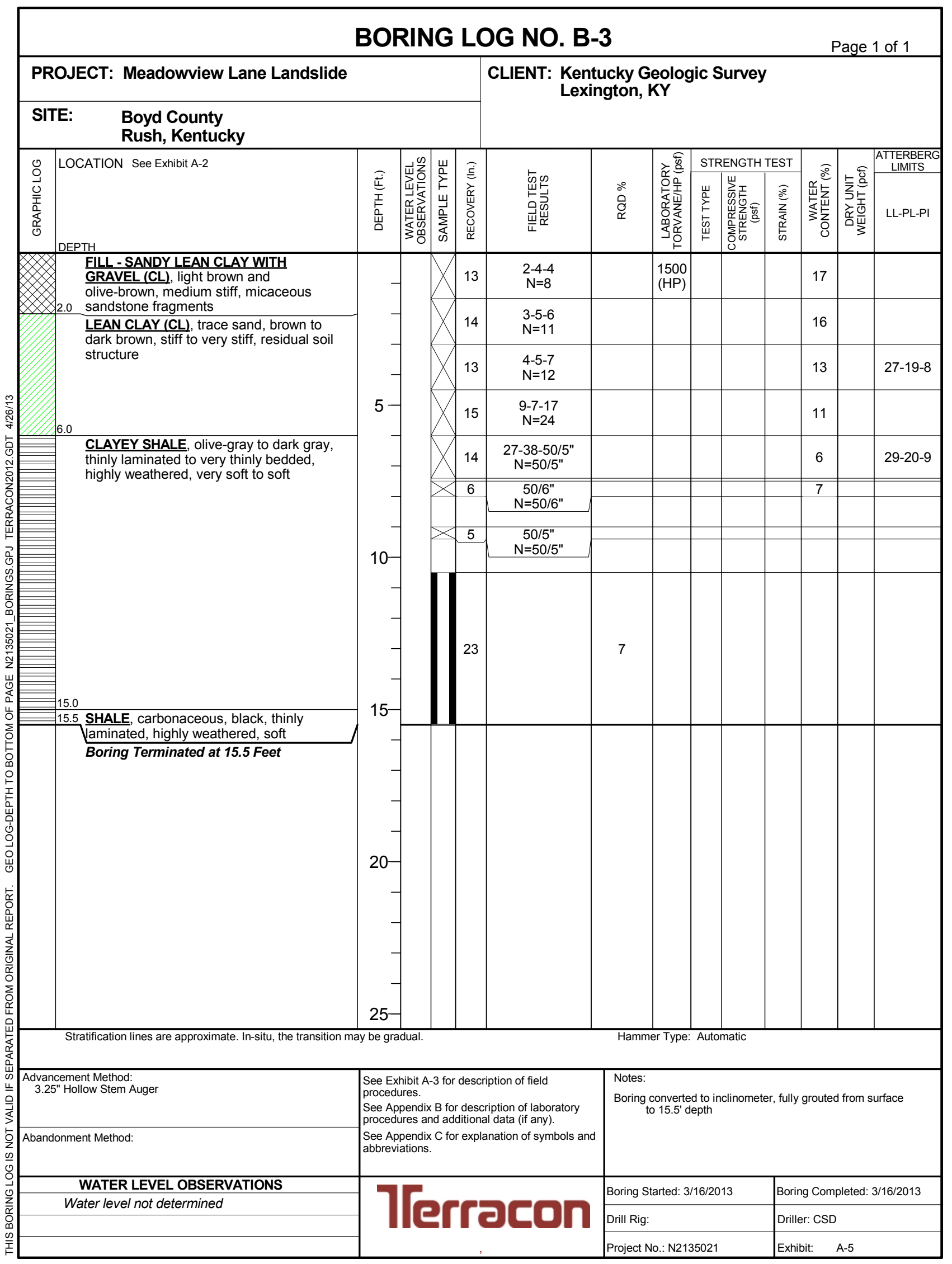




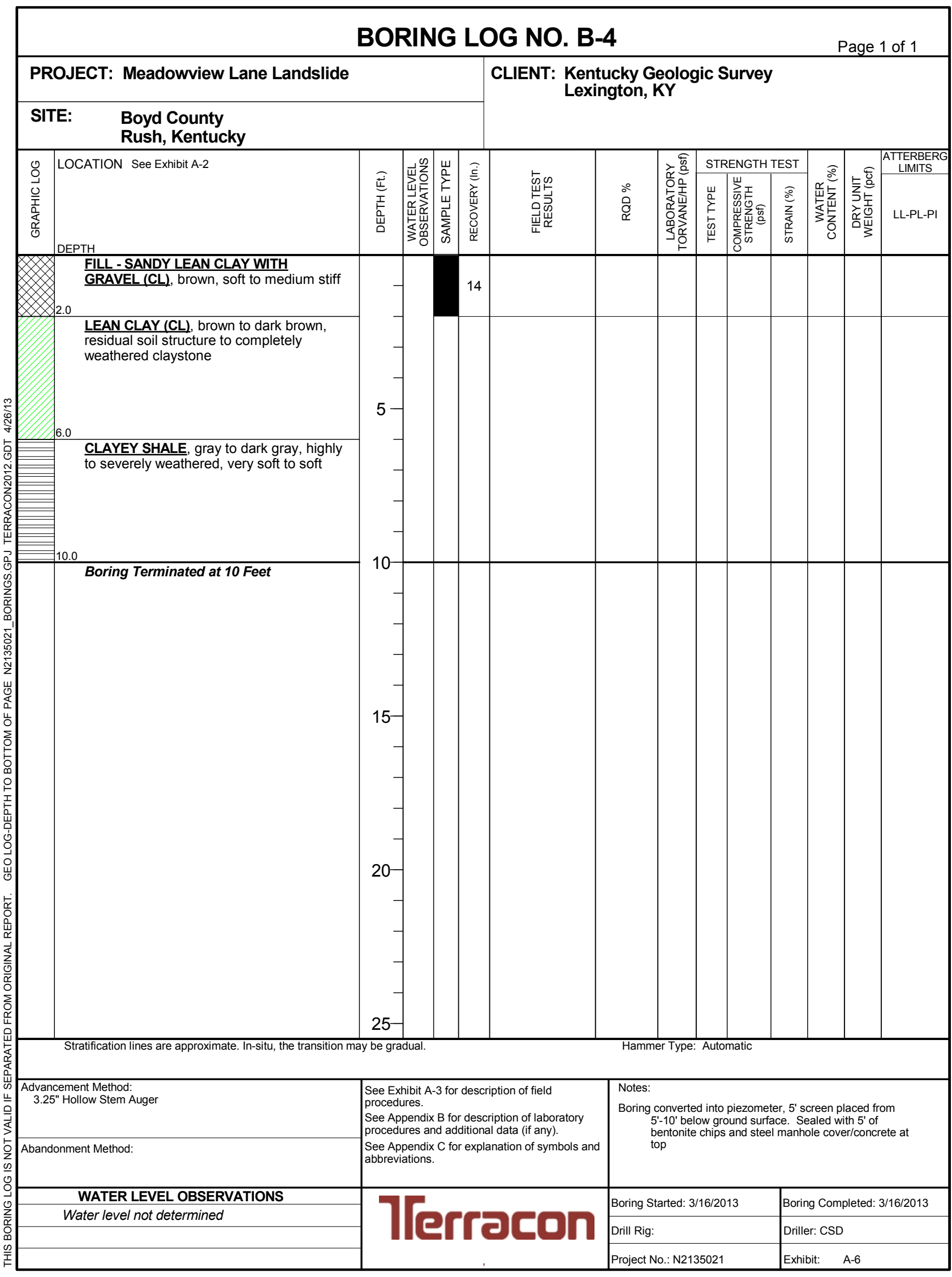




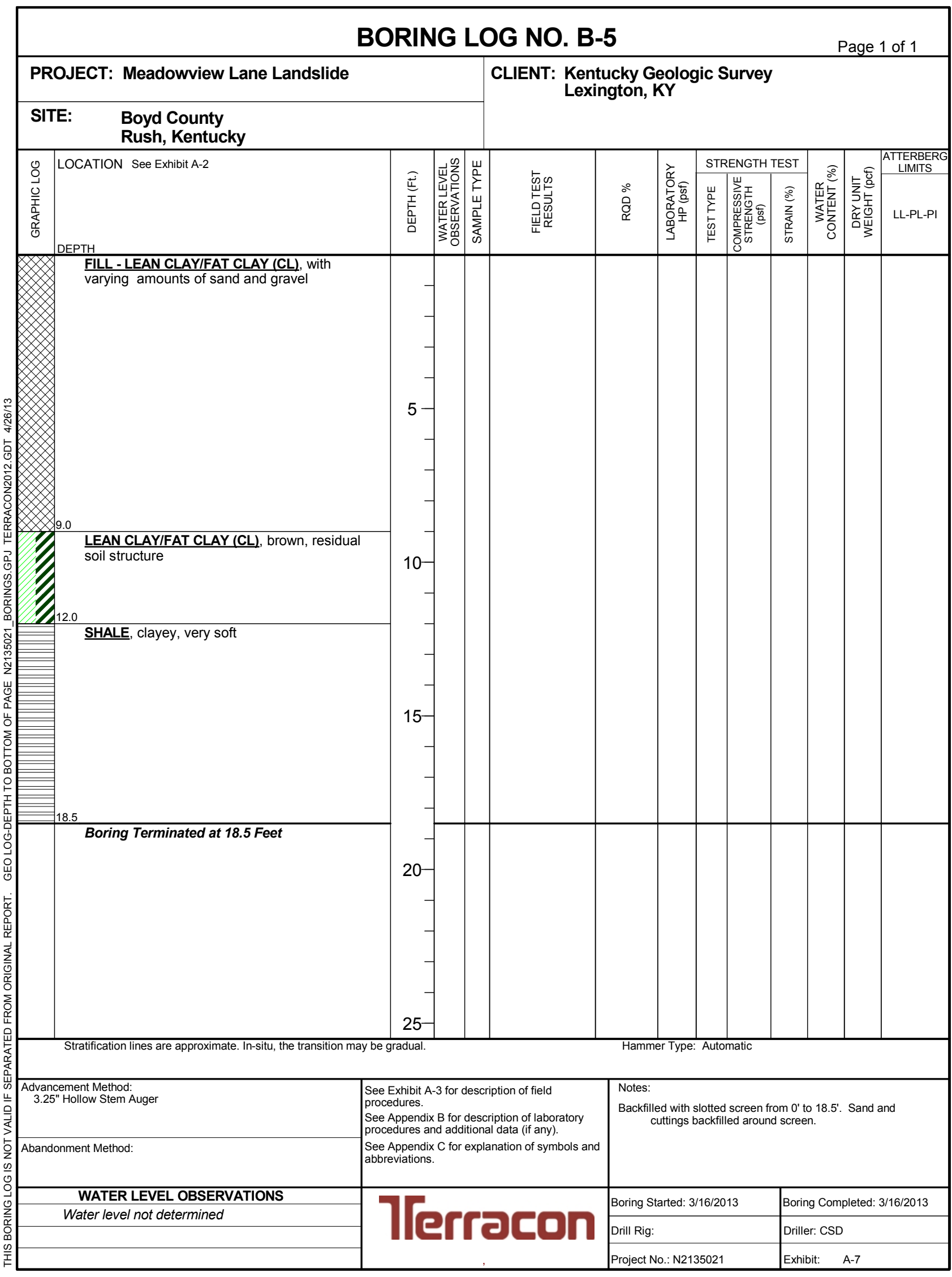




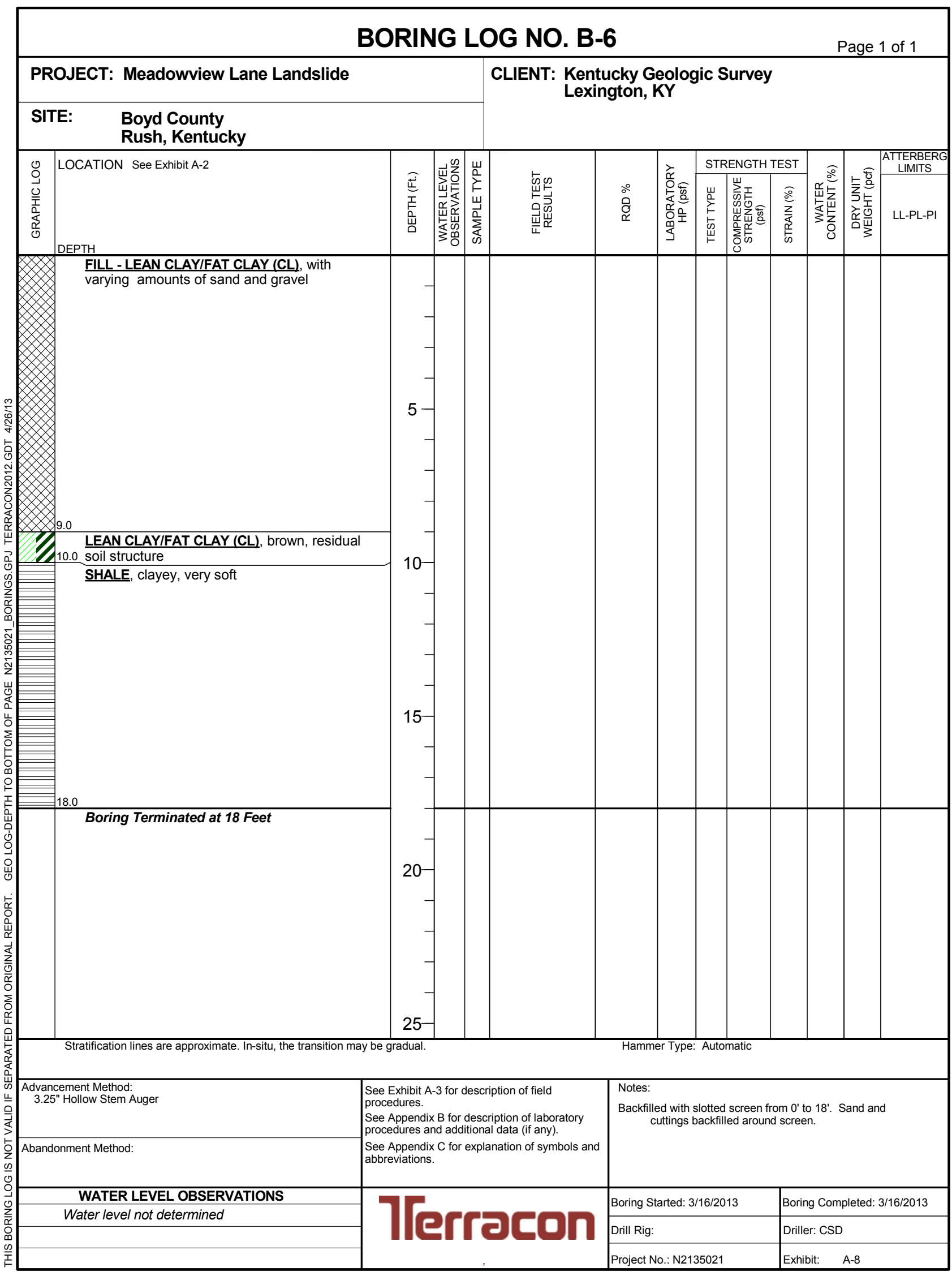


ATTERBERG LIMITS RESULTS ASTM D4318

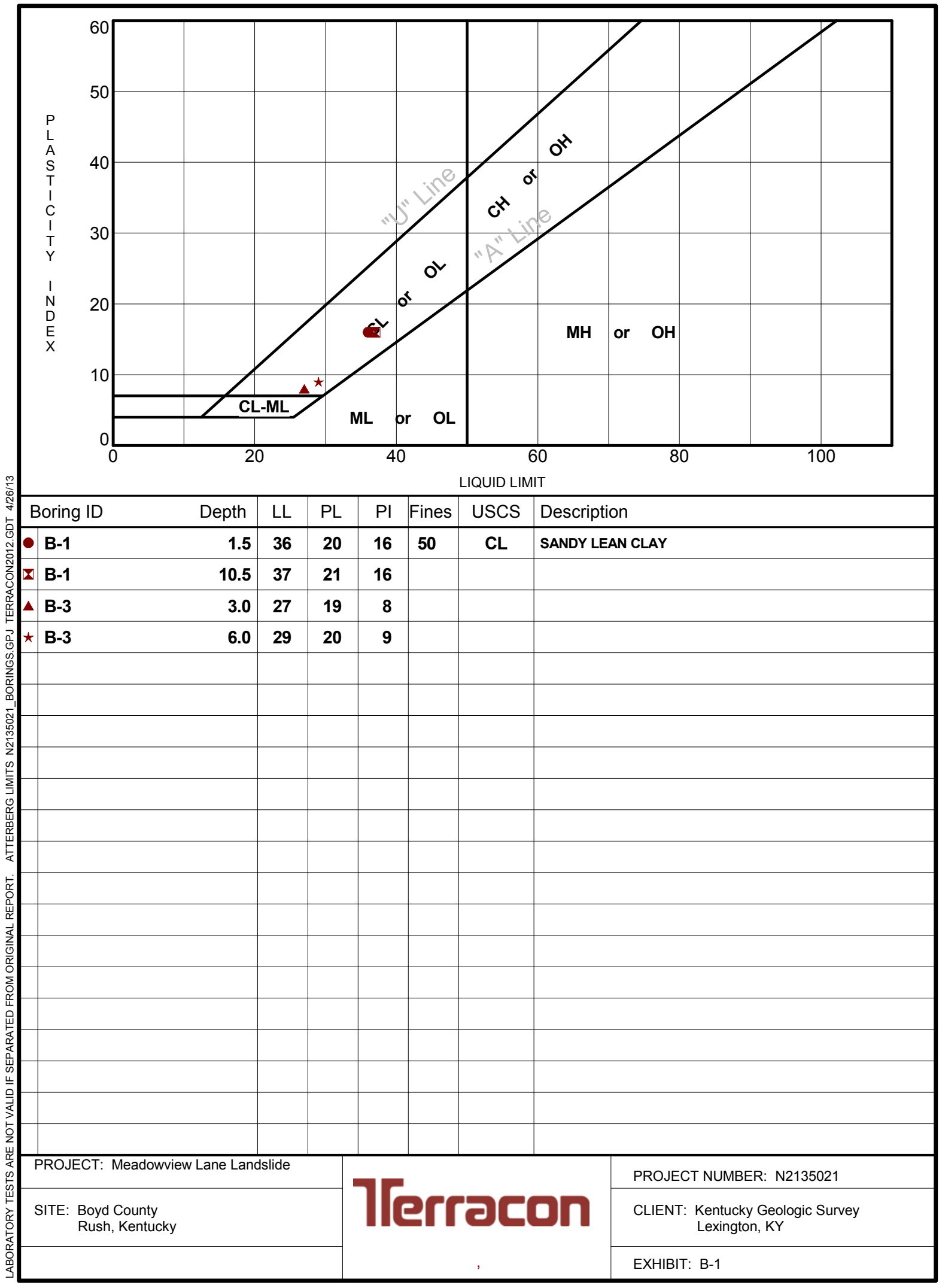


GRAIN SIZE DISTRIBUTION

ASTM D422

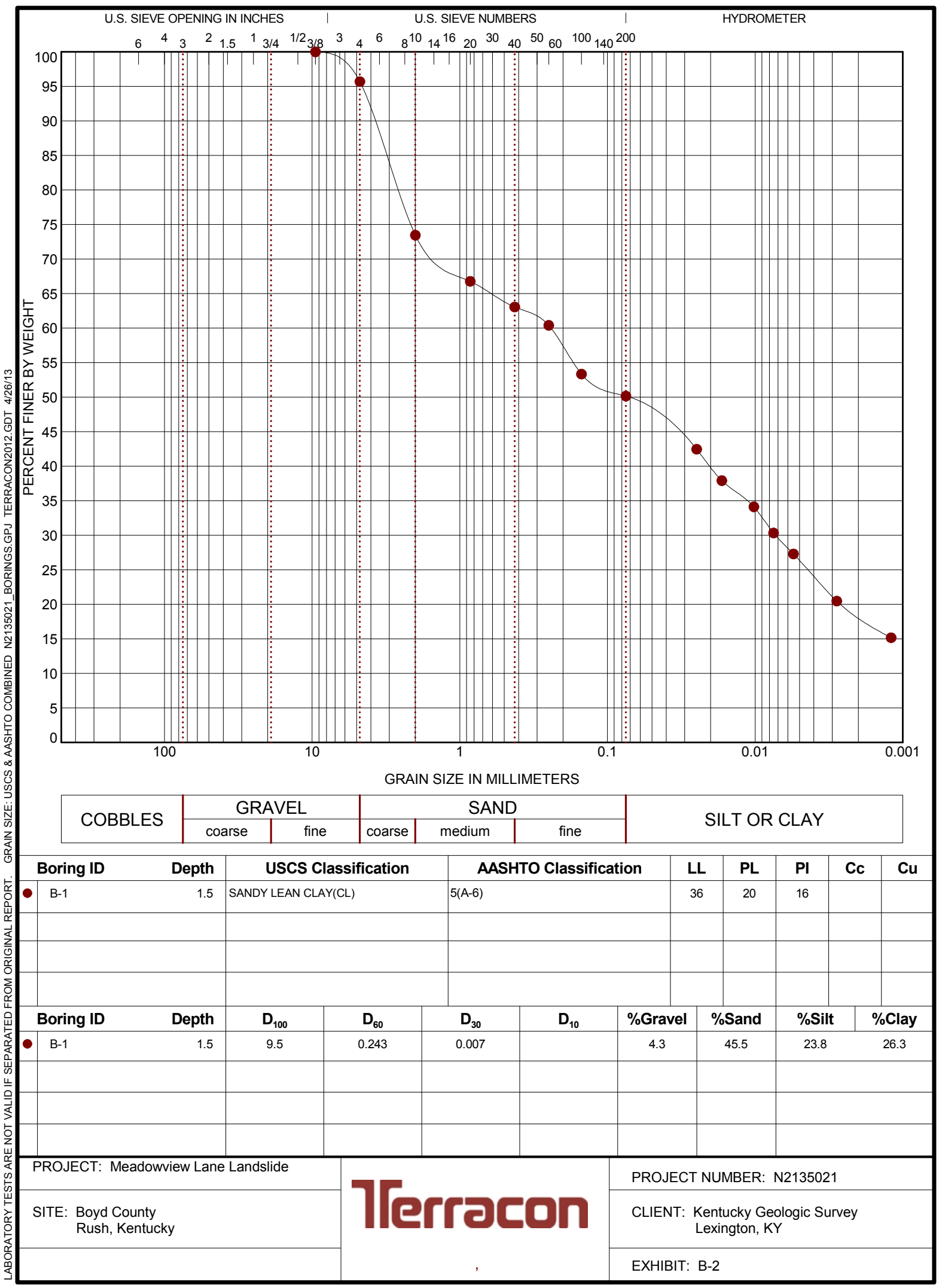


GRAIN SIZE DISTRIBUTION

ASTM D422

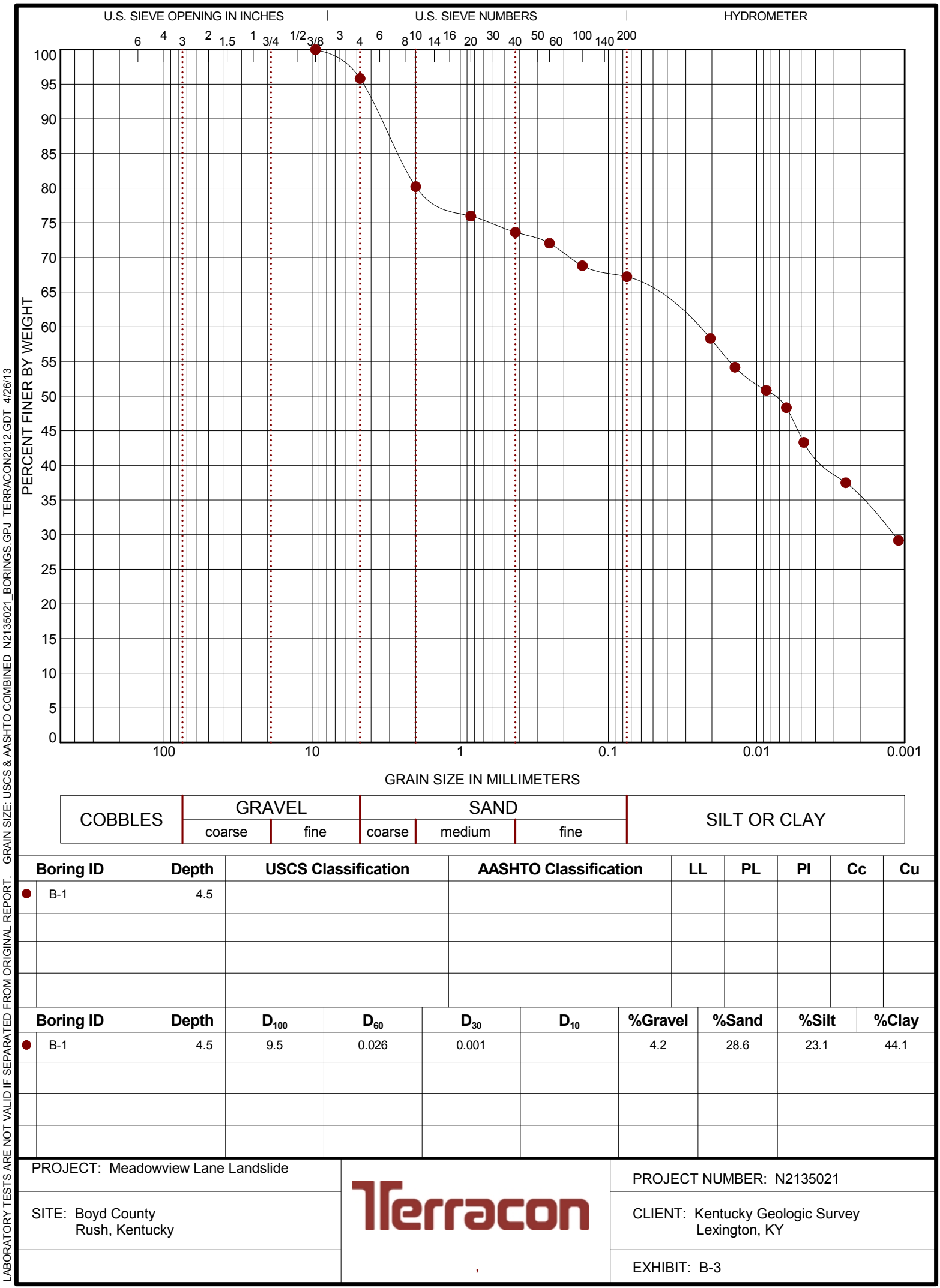


GRAIN SIZE DISTRIBUTION

ASTM D422

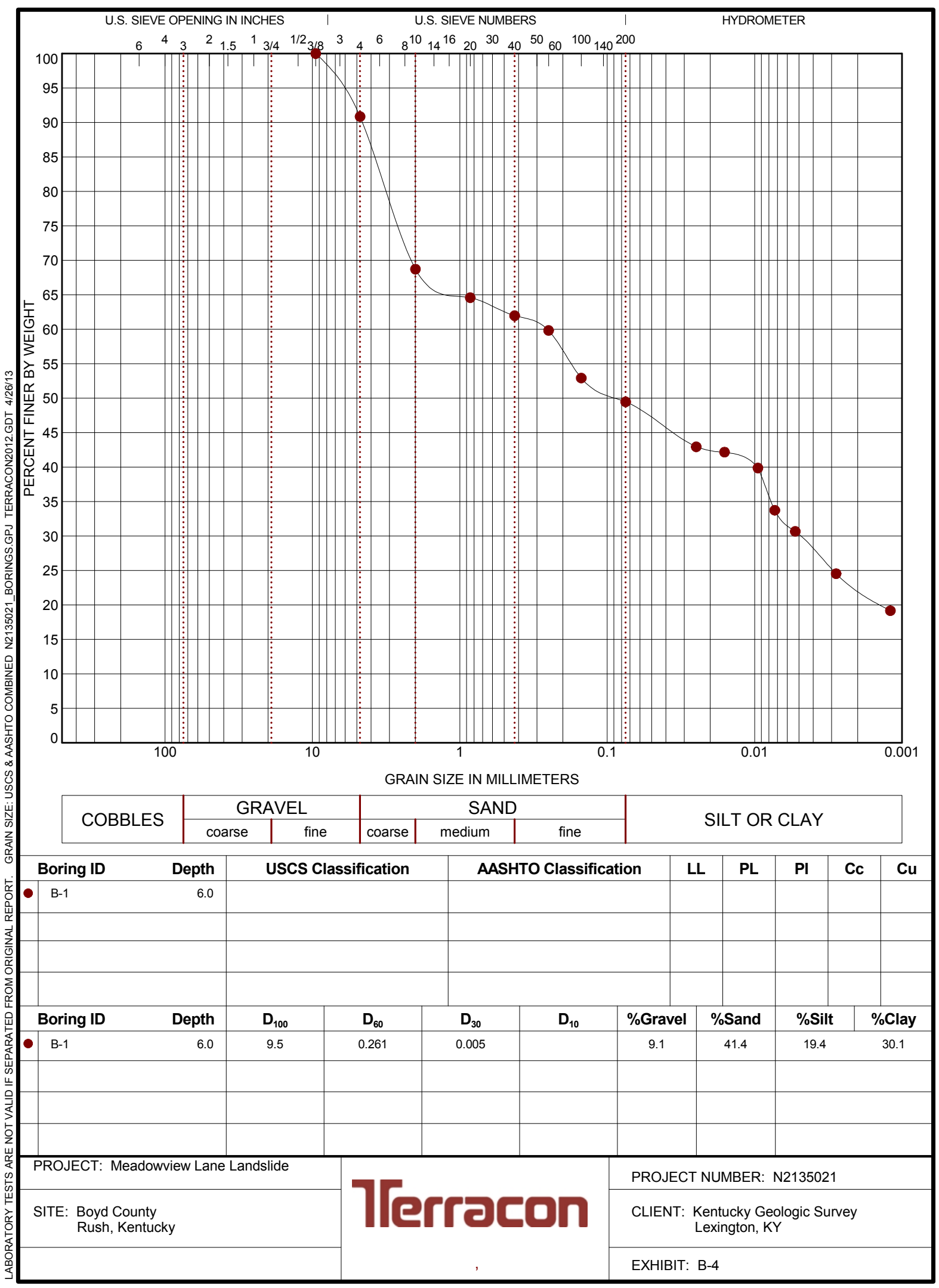


GRAIN SIZE DISTRIBUTION

ASTM D422

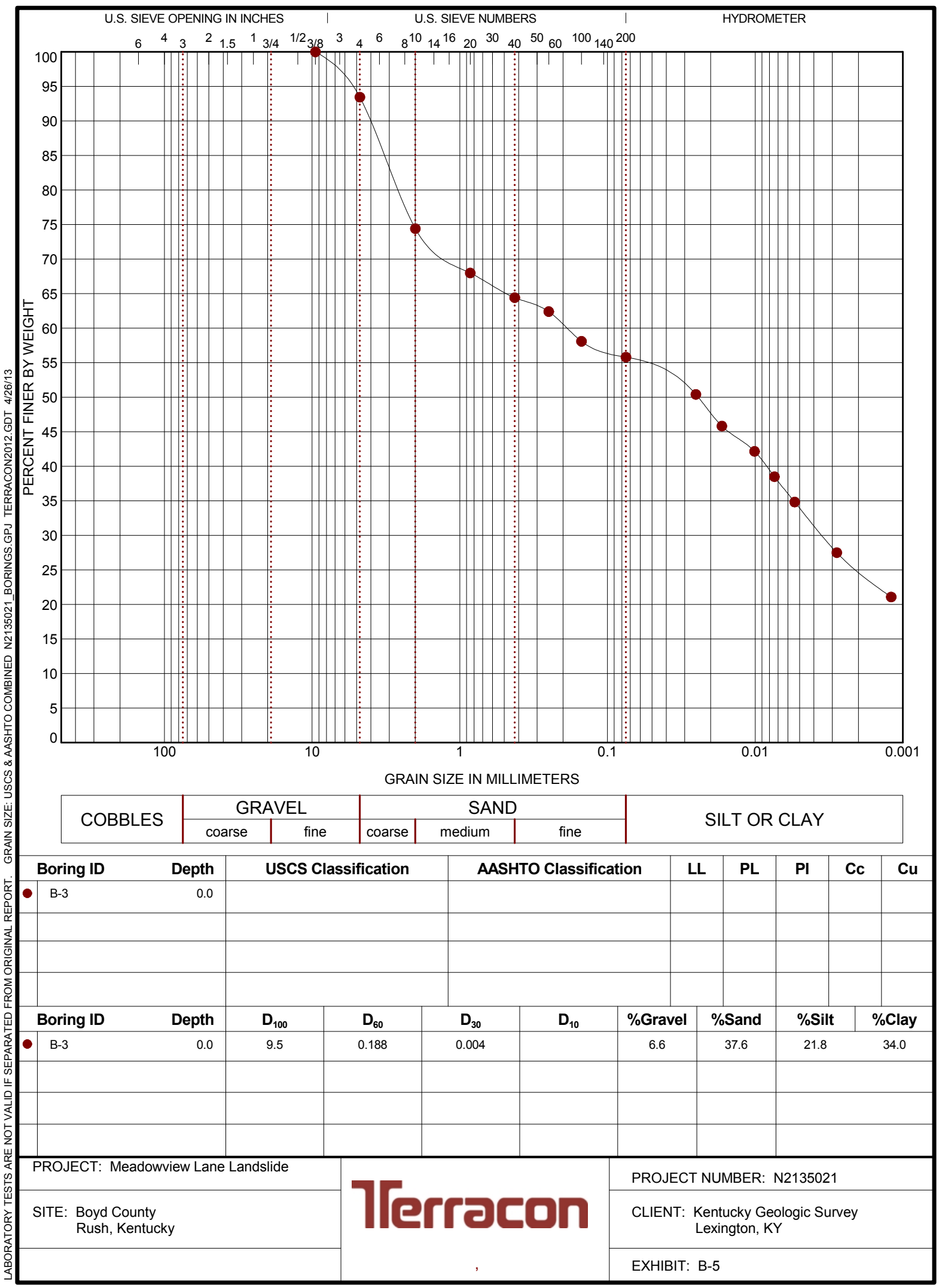




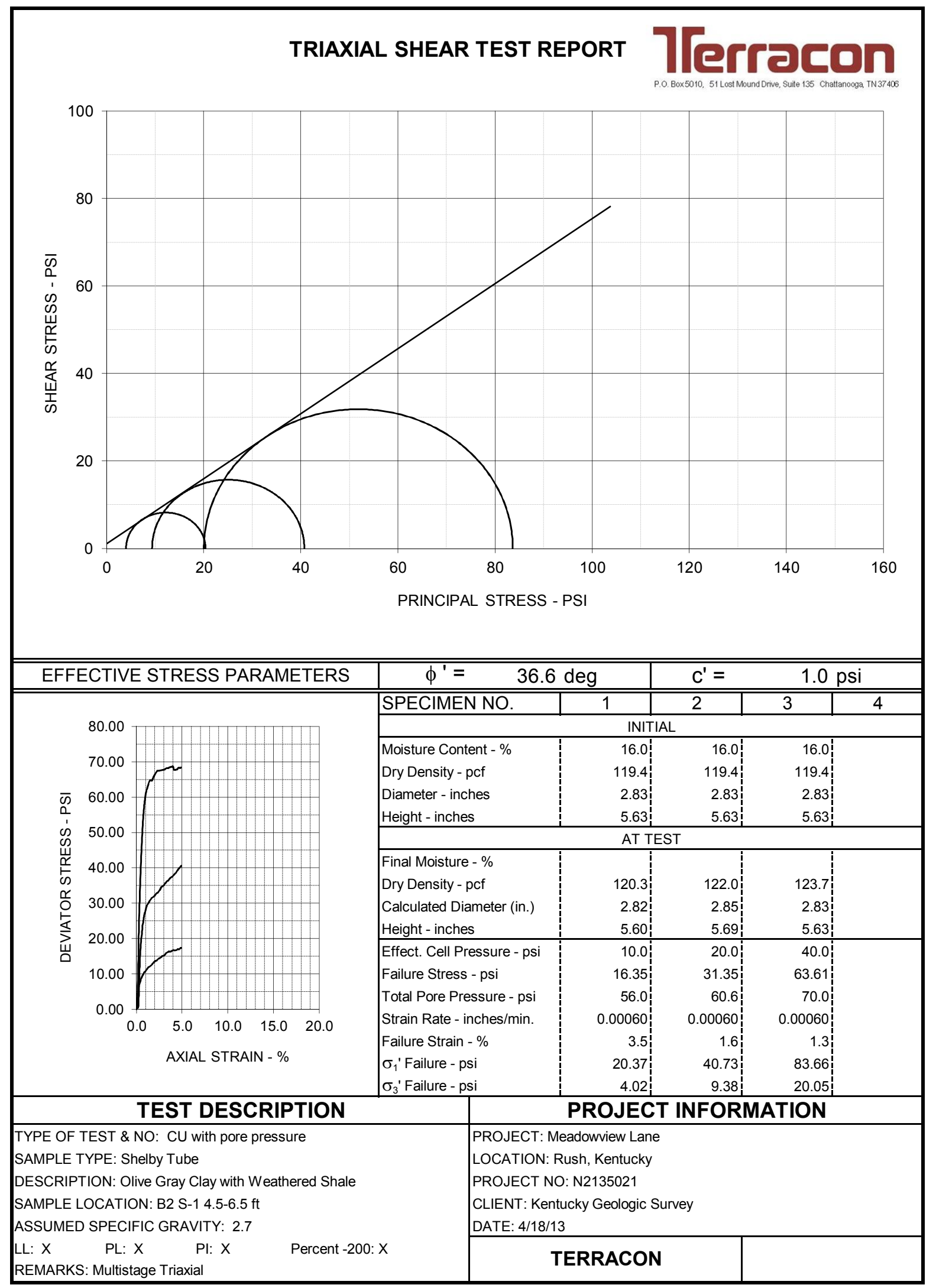




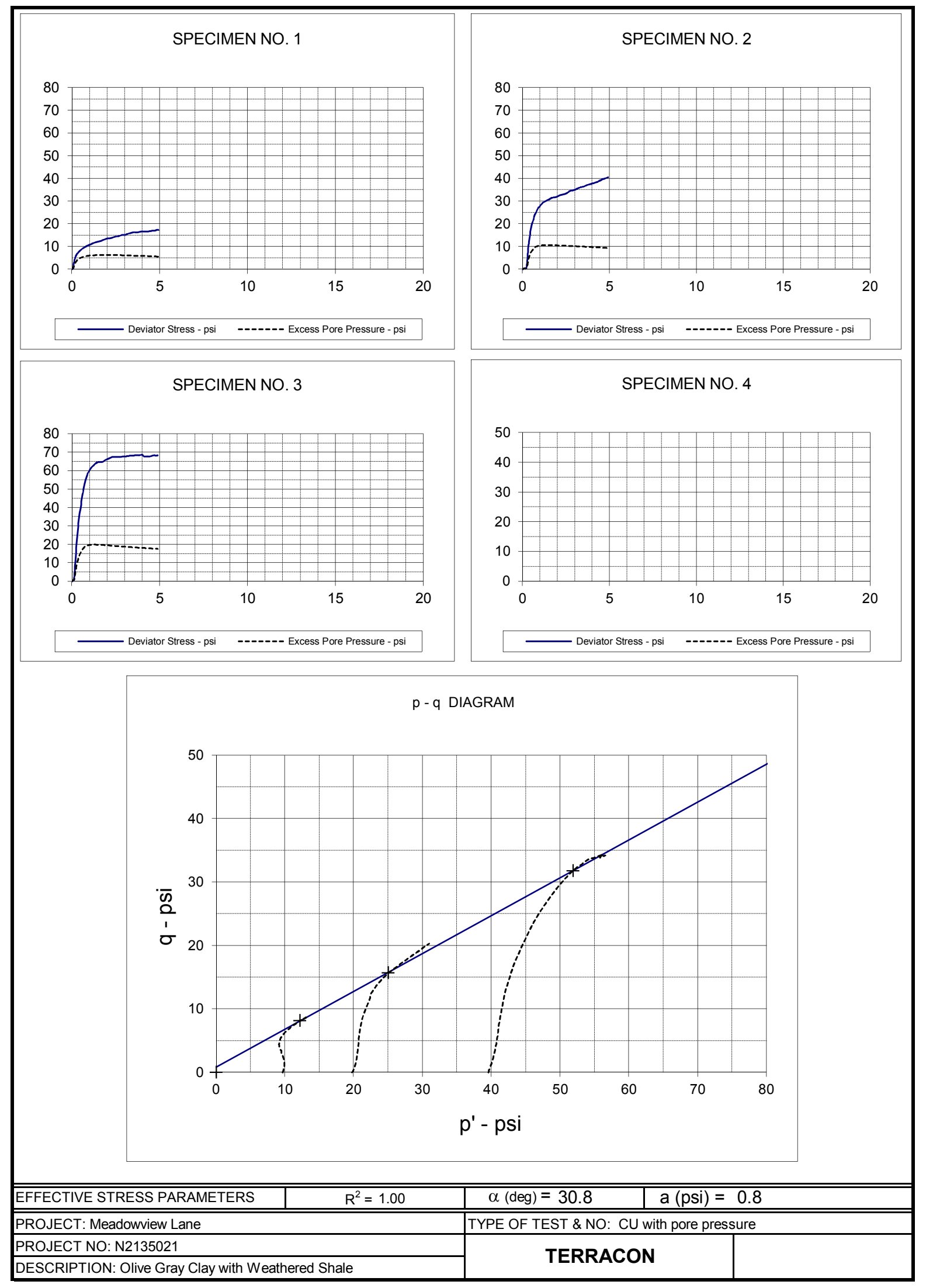




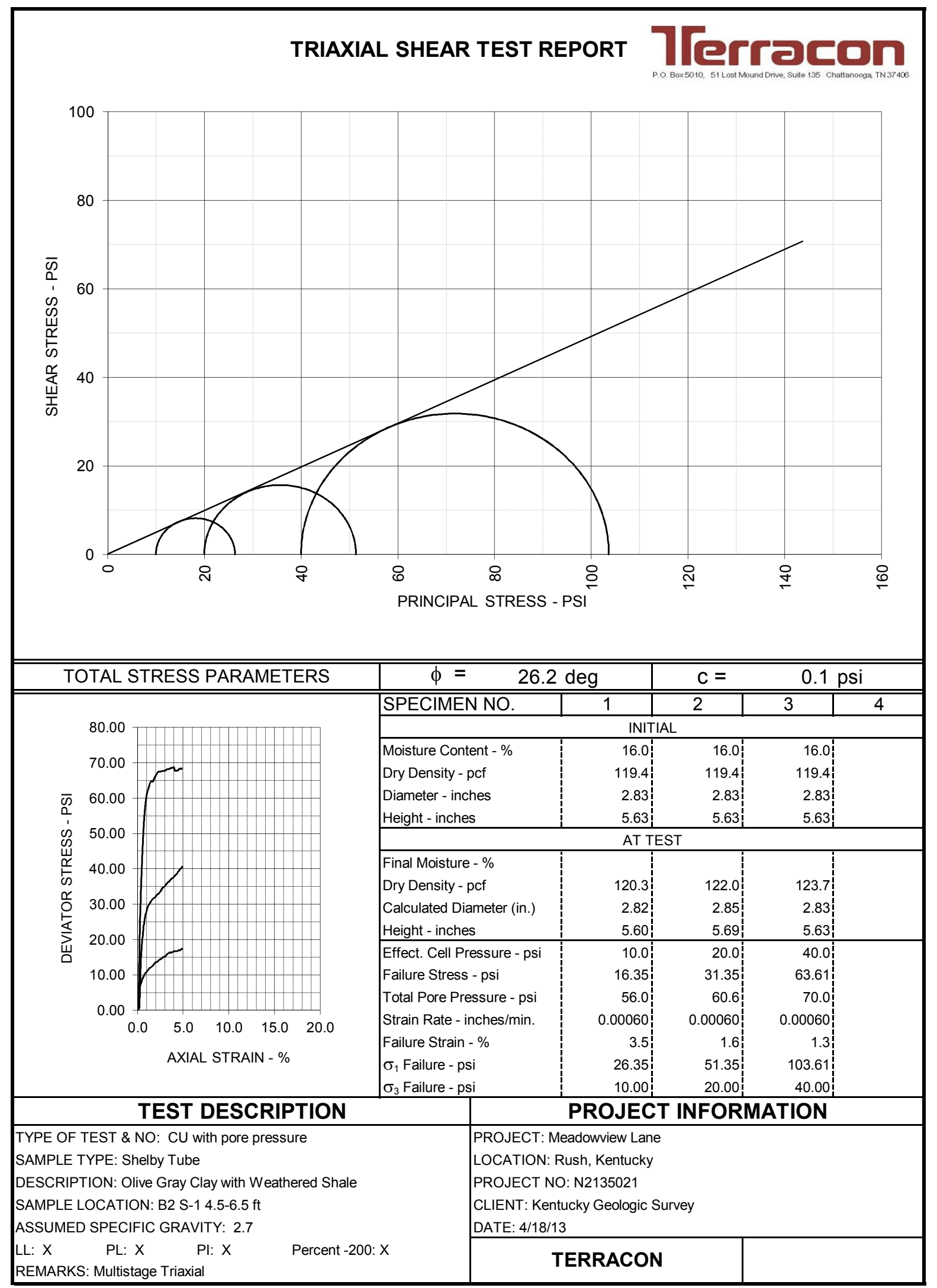




\section{Appendix 2: \\ Cumulative and Incremental Inclinometer Data}




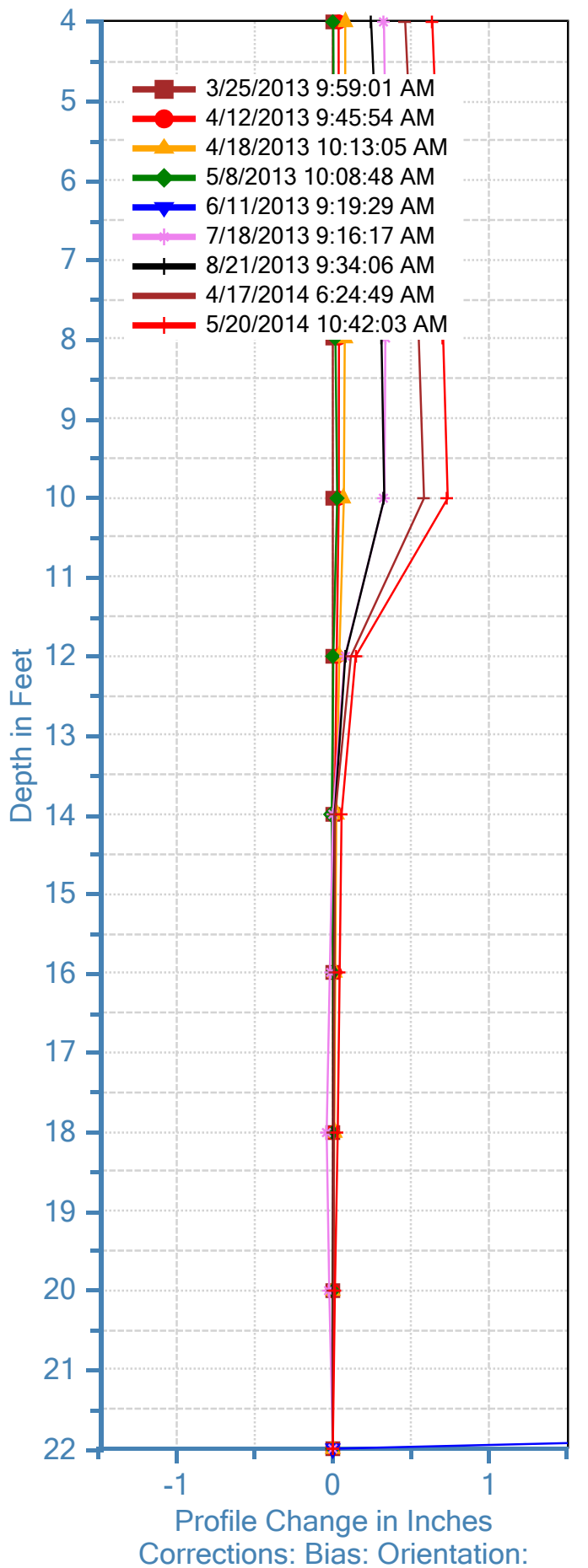

Corrections: Bias: Orientation:

Rotation

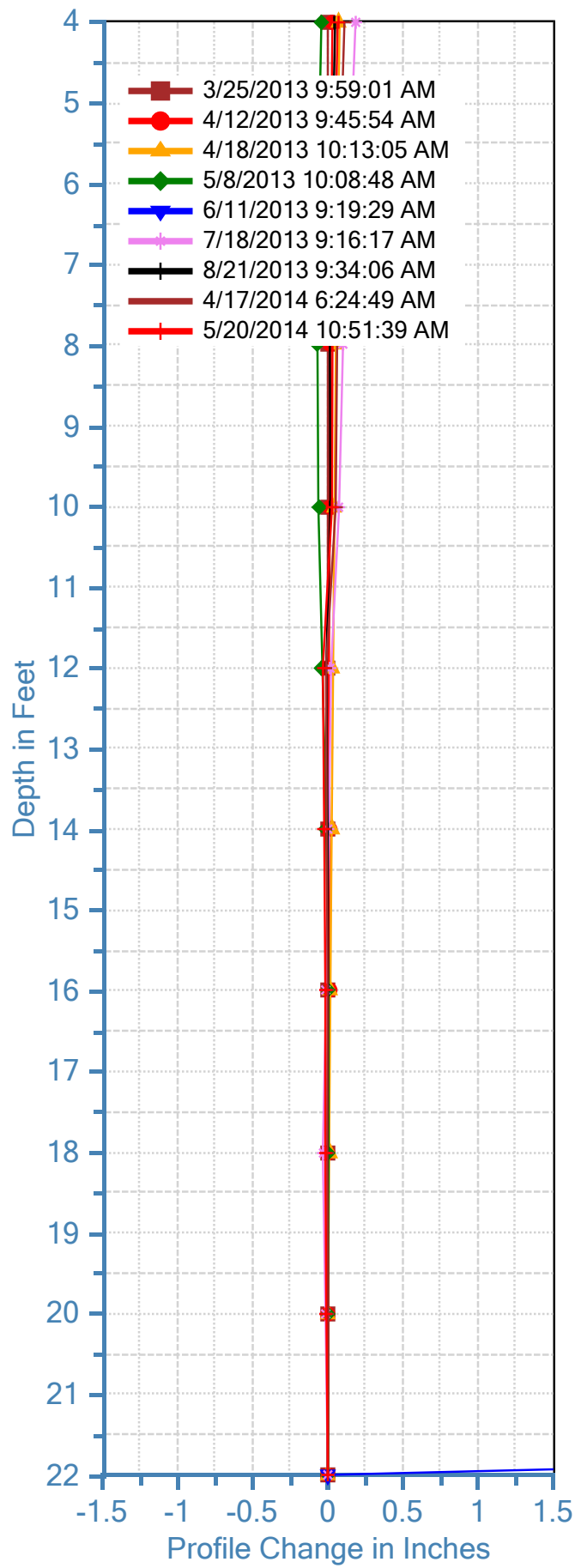

Corrections: Bias: Orientation: Rotation

\section{Terracon Consultants, Inc.} Louisville, $\mathrm{KY}$ 


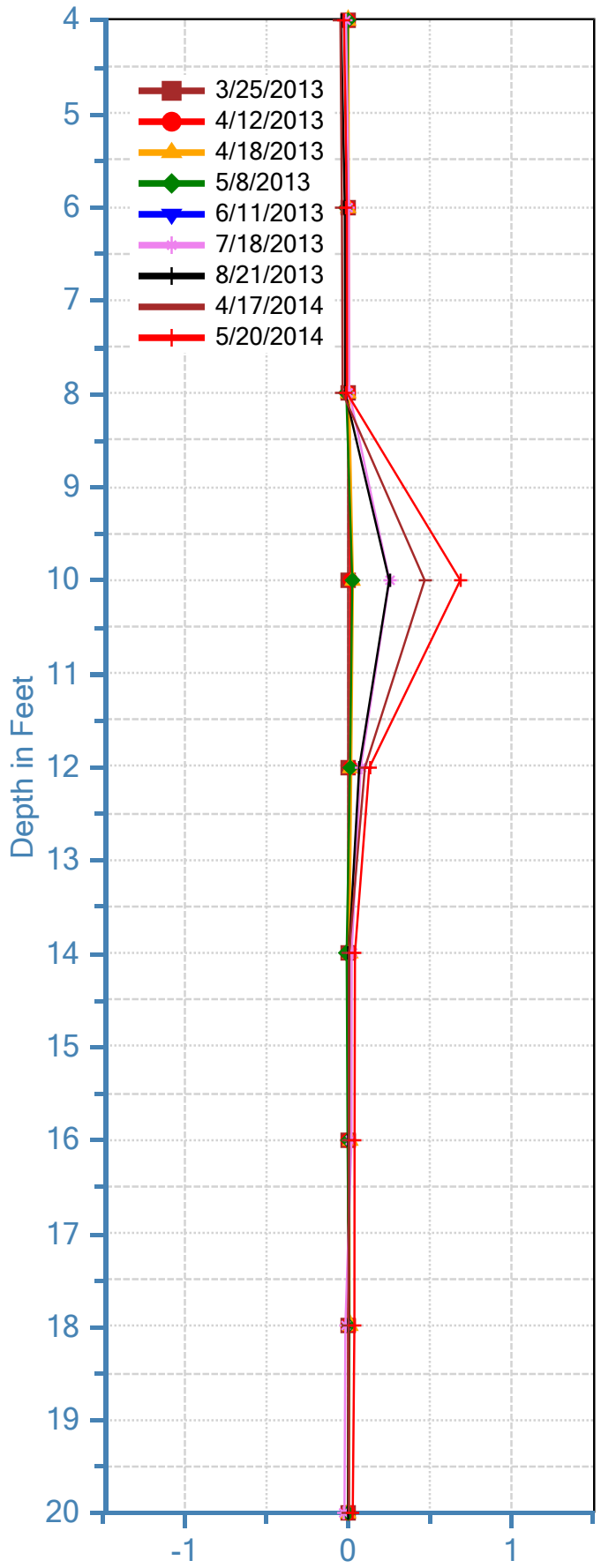

Tilt Change in Inches Corrections: Bias: Orientation: Rotation

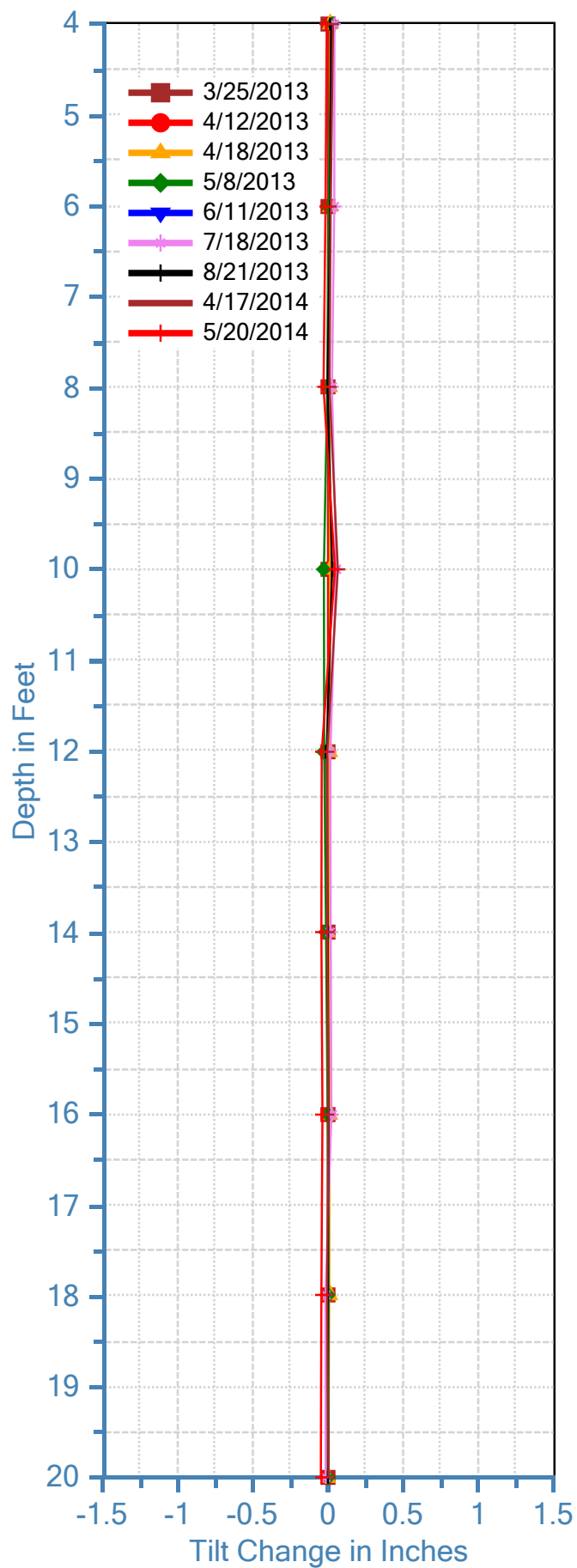

Corrections: Bias: Orientation: Rotation 